
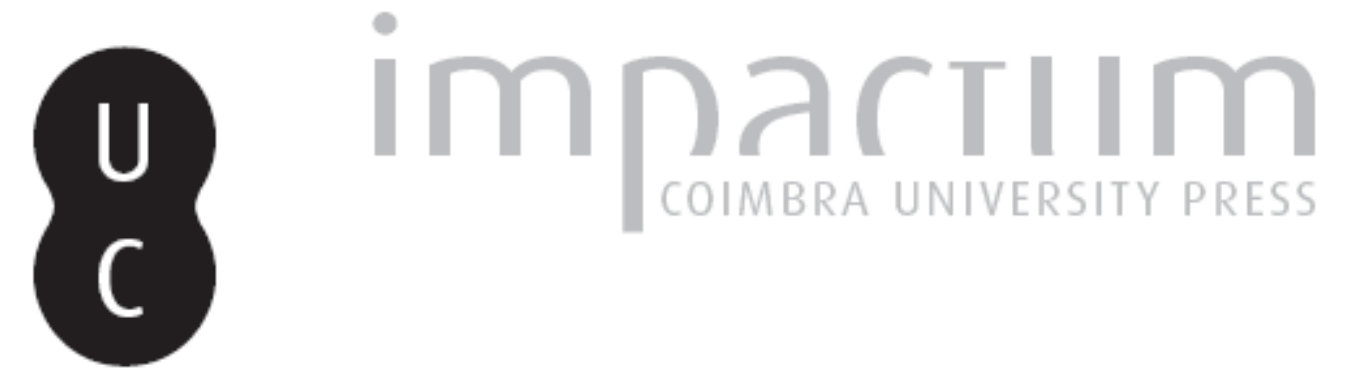

\title{
A numária de Cantnipo
}

\author{
Autor(es): $\quad$ Faria, A. Marques de
}

Publicado por: Imprensa da Universidade de Coimbra

URL persistente:

URI:http://hdl.handle.net/10316.2/45568

DOI:

DOI:https://dx.doi.org/10.14195/1647-8657_28_4

Accessed : $\quad$ 26-Apr-2023 12:01:53

A navegação consulta e descarregamento dos títulos inseridos nas Bibliotecas Digitais UC Digitalis, UC Pombalina e UC Impactum, pressupõem a aceitação plena e sem reservas dos Termos e Condições de Uso destas Bibliotecas Digitais, disponíveis em https://digitalis.uc.pt/pt-pt/termos.

Conforme exposto nos referidos Termos e Condições de Uso, o descarregamento de títulos de acesso restrito requer uma licença válida de autorização devendo o utilizador aceder ao(s) documento(s) a partir de um endereço de IP da instituição detentora da supramencionada licença.

Ao utilizador é apenas permitido o descarregamento para uso pessoal, pelo que o emprego do(s) título(s) descarregado(s) para outro fim, designadamente comercial, carece de autorização do respetivo autor ou editor da obra.

Na medida em que todas as obras da UC Digitalis se encontram protegidas pelo Código do Direito de Autor e Direitos Conexos e demais legislação aplicável, toda a cópia, parcial ou total, deste documento, nos casos em que é legalmente admitida, deverá conter ou fazer-se acompanhar por este aviso.

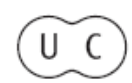


FACULDADE DE LETRAS

INSTITUTO DE ARQUEOLOGIA

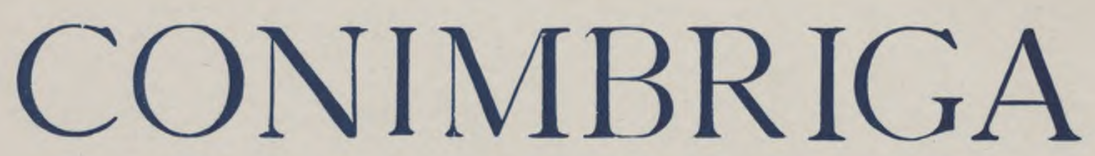

VOLUME XXVIII

UNIVERSIDADE DE COIMBRA

1989 
A. Marques de Faria

Tècnico do Instituto Português do Patrimònio Cultural

A NUMÁRIA DE *CANTNIPO

Conimbriga, XXVIII (1988), p. 71-99

RESUMo: Dado não haver até agora nenhuma interpretação satisfatória para a legenda toponímica em caracteres ibéricos figurada nas moedas tradicionalmente atribuídas a Salacia, decidimos neste trabalho apresentar a leitura *Cantnipum, baseada nos nomes de dois magistrados monetários, Cantnip. e Candnil. Em face das incertezas que ainda impendem sobre a origem da legenda em apreço, é natural que a ocorrência do radical cantn- seja questionada; porém, o mesmo não deverá suceder relativamente ao sufixo -ipum (= lat. -ipo) atestado em numerosos topónimos não indo-europeus do Sudoeste. De igual modo, a análise da onomástica e da tipologia monetária leva-nos a crer na origem não indo-europeia de uma parte da população de *Cantnipo.

SUMMARY : No satisfactory reading of the Iberian legend depicted in bronze coins currently assigned to Salacia hasn't yet been presented. That's the reason why in this work we propose ${ }^{*}$ Cantnipum as an interpretation of this legend. This reading is supported by two magistrates' names written in those coins, Cantnip. and Candnil, otherwise unknown. Given the lack of certainty about the origin of that Iberian legend, the element cantn- may be put in question; however, the suffix -ipum ( = latin -ipo) is known in several place names in southwestern Iberia. Also the personal names as well as monetary types bring us enough evidence of a non-indoeuropean origin of some of ${ }^{*}$ Cantnipo ${ }^{i}$ s inhabitants. 
(Página deixada propositadamente em branco) 


\section{A NUMÁRIA DE *CANTNIPO}

\section{Legenda Toponímica}

A ceca que precedeu Salada no local onde hoje se situa Alcácer do Sal tem concitado, ao longo de mais um século, as atenções de numerosos numismatas e filólogos. Não obstante, continua a ser, nas palavras de Javier de Hoz, a «ceca epigráficamente más enigmática de la Península» ${ }^{1}{ }^{1}$ ). Em boa verdade, todas as tentativas de decifração da legenda toponímica pré-romana representada nas moedas de bronze nela cunhadas redundaram num malogro ao omitirem os dois postulados que lhes deviam ter servido de pedra angular:

a) O topónimo pré-romano com terminação latinizada em -ipo $\left(^{2}\right)$, transmitido por Ptolemeu (II, 5, 2) sob a forma deturpada KaXXÍ7rouç para designar o rio que banhava a cidade com aquele nome $\left({ }^{3}\right)$, é o mesmo que figura na epígrafe ibérica $\left({ }^{4}\right)$ das moedas

(*) Hoz, J. de, Crónica de lingüistica y epigrafía prerromanas de la Península Ibérica: 1979, «Zephyrus», Salamanca, XXX-XXXI, 1980, p. 314.

(2) Müller, C., Claudii Ptolemaei Geographia, I, 1, Paris, Firmin-Didot, 1883, p. 131.

(3) ID., ibid., p. 131; sobre outros casos hispânicos de homonímia entre núcleos urbanos e rios v. Ordóñez Agulla, S. - Colonia Augusta Firma Astigi, Sevilla, Departamento de Historia Antigua de la Universidad de Sevilla, 1988, p. 20.

$\left.{ }^{4}\right)$ No sentido em que este termo é utilizado nas fontes clássicas: v. Domínguez Monedero, A. J., Los términos «Iberia» $e$ «Iberos» en las fuentes grecolatinas: estudio acerca de su origen y ámbito de aplicación, «Lucentum», Alicante, II, 1983, p. 203-224. 
emitidas nos séculos II e I a.C. pela referida cidade (5) que, mais tarde, tomou o nome de Imperatoria Salacia $\left(^{6}\right)$. Esta legenda é composta por seis signos que nos reversos dos asses apresentam a seguinte disposição $\left({ }^{7}\right)$ :

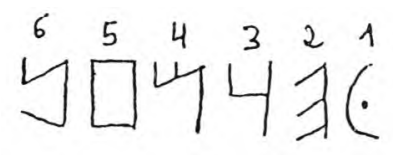

b) A inscrição em apreço possui características únicas: tratando-se de uma excepção numa região em que a prática da escrita não se encontrava, na altura, minimamente divulgada $\left({ }^{8}\right)$, ela resulta da apropriação $a d$ hoc de grafemas provenientes não

$\left(^{5}\right)$ Sobre a identificação do sufixo -ipo na legenda monetária v. LAFon, R., Noms anciens de personnes et de lieux $d u$ Sud de VEspagne d'après les inscriptions, in «Atti e Memorie del VII Congresso Internazionale di Scienze Onomastiche (Firenze, 1961)», III, Firenze, 1963, p. 404; Sснмоць, IL, Zur Entzifferung der südhispanischen Schrift, «Madrider Mitteilungen», Heidelberg, 3, 1962, p. 97; LeJeune, M., Épigraphie sud-hispanique, «Revue des Études Anciennes», Bordeaux, LXV, 1963, p. 30; Siles, J., Léxico de inscripciones ibéricas, Madrid, Ministerio de Cultura, 1985, p. 160, n. ${ }^{\circ} 623$.

${ }^{6}$ ) Zobel DE ZANGróniz, J., Essai d'attribution de quelques monnaies ibériennes à la ville de Salacia, «Revue Numismatique», Paris, nouv. série, VIII, 1863, p. 381-382; Vasconcellos, J. L. de, Les monnaies de la Lusitanie portugaise, «O Archeologo Português», Lisboa, VI, 1901, p. 83-84; a passagem da Geografia de Estrabão relativa ao estuàrio do Sado (III, 3, 1) encontra-se de tal modo corrupta que induziu alguns investigadores a advogar a diferenciação geográfica entre Salacia e a cidade cujo nome é objecto deste nosso trabalho: V. Correa, J. A., Singularidad del letrero indigena de las monedas de Salacia (A 103), «Numisma», Madrid, 177-179,1982, p. 73-74.

$\left.{ }^{7}\right)$ As variantes gráficas são em número superior as que aponta Correa, J. A., op. cit. (v. nota 6), p. 69, nota 3; v., p. ex., Rodríguez de Berlanga, M., Una antigua moneda inédita de España, «Revista de Archivos, Bibliotecas y Museos», Madrid, I, 1897, p. 435; Hü Bner, E., Monumenta Linguae Ibericae, Berlin, Georg Reimer, 1893, p. 136; Untermann, J., Мonumenta Linguarum Hispanicarum, I, Wiesbaden, Dr. Ludwig Reichert Verlag, 1975, p. 343.

(8) Beirão, e. de M. e Gomes, M. V., Grafitos da Idade do Ferro do Centro e Sul de Portugal, in «Actas del III Coloquio sobre Lenguas y Culturas Paleohispánicas (Lisboa, 1980)», Salamanca, 1985, p. 496.

Conimbriga, 28 (1989), 71-99 
apenas de um, mas de distintos semi-silabários em uso no Sul e no Leste da Península $\left({ }^{9}\right)$. A sua singularidade é ainda comprovada quer pela criação de um grafema copiado de um símbolo astral presente nas moedas de Gadir jGades $\left({ }^{10}\right)$ que serviram de modelo às primeiras emissões $\left({ }^{11}\right)$, quer pelas variantes gráficas detectáveis noutros caracteres $\left({ }^{12}\right)$. Este último fenómeno, aliado à arbitrariedade na escolha da parte da legenda a gravar quando, por falta de espaço, a sua representação completa não era exequível ( $\left.{ }^{13}\right)$, parece reflectir o desconhecimento do seu significado por parte de alguns signatores $\left({ }^{14}\right)$.

Foi com base nestas proposições que enveredámos pelo único caminho que nos pareceu conduzir à sua decifração: tentar encontrar nos letreiros latinos que ocorrem na maioria das emissões algum vocábulo foneticamente afim do potamónimo veiculado por Ptolemeu. Ora, em 1972, M. Farinha dos Santos publicou um desses numismas onde leu a inscrição CANTNIP, dando a entender tratar-se do nome (abreviado) de um magistrado até então desconhecido $\left({ }^{15}\right)$. Até que surjam provas definitivas que confirmem ou refutem esta nossa hipótese, julgamos estar perante

${ }^{9}$ Lafon, R., Pour Vétude de la couche linguistique pré-indo-européenne $d u$ Portugal, in "Actas do IX Congresso Internacional de Linguística Românica (Lisboa, 1959)», I, Lisboa, 1961, p. 30-31; I ., op. cit. (y. nota 5), p. 404.

(10) A sua colocação no campo dos reversos de ambas as amoedações é praticamente a mesma: v. Villaronga, L., Numismática antigua de Hispania, Barcelona, Cymys, 1979 , p. 75, n. ${ }^{\circ} 156$ e p. 160, n. ${ }^{\circ} 413$.

(11) Crawford, M. H., Coinage and money under the Roman republic, London, Methuen, 1985, p. 214.

(12) Y. nota 7.

(13) V. infra, moedas n.os 3, 13, 14 e 20.

(14) García-Bellido, M. ${ }^{\mathrm{a}}$ P., Leyendas e imágenes púnicas en las monedas «l ib io fenices», «Yeleia», Vitoria, 2-3, 1985-1986, p. 500, nota 7.

(15) Santos, M. F. dos, Moedas hispânicas recolhidas na Cabeça de Vaiamonte (Monforte, Alto Alentejo), «Anais da Academia Portuguesa da História», Lisboa, 2. ${ }^{\text {a }}$ série, 21, 1972, p. 495; um outro numisma, idêntico a este, já havia sido publicado por Almeida, F. de, Ruínas de Miróbriga dos Célticos, Setúbal, Junta Distrital de Setúbal, 1964, p. 66 e Est. XXVIII, Fig. 84, sem que, contudo, tivesse apresentado qualquer leitura da legenda latina. 
uma forma abreviada do topónimo — * Cant nip (o) (u) — ou, mais provavelmente, perante um antropònimo dele derivado — ${ }^{*}$ Cantnip(ius) $\left({ }^{17}\right)$ ou ${ }^{*}$ Cantnip(onensis) $\left({ }^{18}\right)$. Parece-nos também ser este o caso do nome Candnil, presente em asses $\left({ }^{19}\right)$ e semisses $\left({ }^{20}\right)$. Importa sublinhar que o radical Cantn- só se encontrava atestado até ao momento como cognomen sob a forma CANTNEC[...] numa inscrição atribuída a Antikaria (21).

Em conformidade com a nossa hipótese, a transliteração dos signos em questão processar-se-á do seguinte modo :

O signo 1 que, pela sua semelhança com um símbolo astral, tardou a ser reconhecido (22), deverá corresponder à sílaba $c a$. Em apoio desta leitura surge apenas o hidrónimo ptolemaico, já que este grafema não se encontra em nenhum dos sistemas de escrita exclusivamente ibéricos $\left({ }^{23}\right)$. A orientação que apresenta nos letreiros dos asses mantém a posição do símbolo astral das moedas de Gadir ; Gades $\left({ }^{24}\right)$, sendo admissível a influência, a nível gráfico, de

(16) Sisip(o): V. Vives Y Escudero, A., La moneda hispánica, Madrid Real Academia de la Historia, 1926, Est. CXIV, n. ${ }^{\circ} 1$.

(17) Acinippius: v. HÜ B N E R, E., Corpus Inscriptionum Latinarum, II, Berlin, Georg Reimer, 1869, p. 435, n. ${ }^{\circ} 3238$.

(18) Ostip(onensis) : ID., ibid., p. 198, n. ${ }^{\circ} 1450$; v. igualmente o nome pessoal aquitano Seniponnis (gen., mase.): Gorrochategui Churruca, J., Estudio sobre la onomástica indígena de Aquitania, Bilbao, Universidad del País Vasco, 1984, p. 84, 263 e 367.

(19) Faria, A. M. de, Algumas considerações a propósito do Album de la antigua colección Sánchez de la Cotera de moneda ibero-romana (Madrid, 1986), «Numismática», Lisboa, 48, 1988, p. 9, nota 9; v. infra, moedas n.os 10 e 11.

${ }^{20}$ Vasconcellos, J. L. de, Excursão arqueológica à Estremadura transtagana, «O Archeologo Português», Lisboa, XIX, 1914, p. 305; v. infra, moeda $\mathrm{n} .{ }^{\circ} 14$; a propósito da expressão da origo pessoal nalguns antropónimos ibéricos V. Palomar LaPesa, M., Antroponimia prerromana, in «Enciclopedia Lingüística Hispánica», I, Madrid, Consejo Superior de Investigaciones Científicas, 1960, p. 381; UntermanN, J., Eigennamen auf iberischen Inschriften, in «Actas del II Coloquio sobre Lenguas y Culturas Prerromanas de la Península Ibérica (Tübingen, 1976)», Salamanca, 1979, p. 43.

(21) Hü BNER, E., op. cit. (v. nota 17), p. 281, n. ${ }^{\circ} 2051$.

${ }^{(22)}$ VIVES Y ESCUdERO, A., op. cit. (v. nota 16), p. LXXVI.

(23) Correa, J. A., op. cit. (v. nota 6), p. 70-71.

(24) V. nota 10. 
um ou de vários signos neo-púnicos $\left({ }^{2 \mathrm{~S}}\right)$. Curiosamente, em todas as séries de divisores a que tivemos acesso, este signo não se encontra figurado $(26)$.

O signo 2 deverá traduzir-se pelo valor consonántico $d / t$ ao qual Gómez-Moreno acrescentou um timbre vocálico que neste caso parece não possuir $\left({ }^{27}\right)$.

Indo de encontro aos autores que o valorizam como w $\left({ }^{28}\right)$, cremos que o signo 3 deverá ser alógrafo do $m$ utilizado nas primeiras inscrições celtibéricas $\left({ }^{29}\right)$ e do w pertencente aos outros semi-silabários peninsulares. Embora esta grafia constitua uma excepção, podem encontrar-se paralelos para ela em grafitos de Ensérune e Pech Maho, no Sudoeste da Gália( $\left.{ }^{30}\right)$. Se Untermann já havia chamado a atenção para a afinidade gráfica entre este signo e o $n$ ibérico dos numismas por ele observados ( $\left.{ }^{31}\right)$, por outro lado,

(2Õ) Vives y ESCUdero, A., op. cit. (v. nota 16), p. LXXVI; Solá-Solé, J. M., El alfabeto monetario de las cecas «libio-fenices», Barcelona, Puvill, 1980, p. 89, Est. II.

(26) Excepto, talvez, numa série de semisses que se manteve inédita até 1979, ano em que foi publicado um exemplar a ela pertencente : V. VILLARONGA, L., op. cit. (v. nota 10), p. 166, n. ${ }^{\circ} 474$; v. infra, moedas n. ${ }^{\text {ss }} 7$ a 9 ; a menos que se trate de um mero símbolo astral, este signo parece surgir isolado em posição sinistrorsa sobre o resto da legenda.

(27) Gómez-Moreno, M., La escritura bástulo-tur detana (primitiva hispánica), «Revista de Archivos, Bibliotecas y Museos», Madrid, LXIX, 1961, p. 891 ; Hoz, J. de, La epigrafia prelatina meridional en H spania, in «Actas del I Coloquio sobre Lenguas y Culturas Prerromanas de la Península Ibérica (Salamanca, 1974)», Salamanca, 1976, p. 261-262; sobre o problemático silabismo de alguns signos que integram os diversos semi-alfabetos ibéricos v., entre outros, Lejeune, M., Celtiberica, Salamanca, Universidad de Salamanca, 1955, p. 44-45; LAF ON, R., op. cit. (v. nota 5), p. 401-402 e 404; UnterMANN, J., op. cit. (v. nota 7), p. 74; Siles, J., Sobre un posible préstamo griego en ibérico, Valencia, Diputación Provincial, 1976, p. 29-30, nota 107; Correa, J. A., Ibérico: Cast(i)lo, Ibolc(a). Latín: Castulo, Obulto, «Habls», Sevilla, 14, 1983, p. 108-109.

(28) ID., op. cit., (v. nota 6), p. 71.

${ }^{(29)}$ Siles, J., Sobre o signo ibérico Y y los valores de las nasales en la escritura ibérica, "Emerita», Madrid, XLIX, 1981, p. 90-92; Fatás, G., Una lésera cortonense, in «Symbolae Ludouico Mitxelena septuagenario oblatae», I, Vitoria, 1985, p. 426.

( ${ }^{30}$ ) Untermann, J., Monumenta Linguarum Hispanicarum, II, Wiesbaden, Dr. Ludwig Reichert Verlag, 1980, p. 152, 243, 251 e 330.

(31) ID., op. cit. (v. nota 7), p. 343. 
J. de Hoz $\left({ }^{32}\right)$ pretendeu encontrar no mesmo signo a origem do grafema $\mathrm{Y}$, que na Celtibéria valia por $n\left({ }^{33}\right)$ ou, mais raramente, por $u\left({ }^{34}\right)$, representando nalguns vocábulos ibéricos o fonema $m\left({ }^{3 \mathrm{~S}}\right)$.

Quanto ao signo 4, a sua transliteração para $i$ não oferece quaisquer dificuldades $\left({ }^{36}\right)$.

O signo 5, documentado na Celtibéria e no Levante ibérico, corresponderá a $p u ; b u\left({ }^{37}\right)$.

Atestado em duas legendas monetárias celtibéricas $\left({ }^{38}\right)$, o signo 6 deverá ser transcrito por $m$.

Assinale-se, por fim, mais um possível ponto de contacto com a Celtibéria: tal como nalgumas epígrafes monetárias daquela zona, a nasal que figura nas legendas latinas antes da dental é omitida na inscrição indígena $\left.{ }^{39}\right)$.

(32) Hoz, J. de, On some problems of Iberian script and phonetics, in «Actas del II Coloquio sobre Lenguas y Culturas Prerromanas de la Península Ibérica (Tübingen, 1976)», Salamanca, 1979, p. 268-269.

(33) Untermann, J., Las leyendas monetales, in «Actas del I Coloquio sobre Lenguas y Culturas Prerromanas de la Península Ibérica (Salamanca, 1974)», Salamanca, 1976, p. 217-218.

(34) Medrano Marqués, M. M. a e díaz Sanz, M.a A., Inscripción ibérica sobre vasija tipo «Ilduradin» hallada en Contrebia Belaisca (Botorrita, Zaragoza), in «Estudios en homenaje al Dr. Antonio Beltrán Martínez», Zaragoza, Universidad de Zaragoza, 1986, p. 603-605.

(35) Tovar, A., El signo Y del ibérico y un descubrimiento de Michelena, in «Symbolae Ludouico Mitxelena septuagenario oblate», I, Vitoria, 1985, p. 463-468; v. igualmente ANGot, P., Pour une lecture affinée de Valphabet ibère, «Archivo de Prehistoria Levantina», Valencia, XIX, 1989, p. 117-119.

(36) Correa, J. A., op. cit. (v. nota 6), p. 71.

(37) Lafon, R., op. cit. (v. nota 5), p. 404; Villaronga, L., op. cit. (v. nota 10), p. 186.

(38) Hǘbner, E., op. cit. (v. nota 7), p. 79, 136; Correa, J. A., op. cit. (v. nota 6), p. 72; este signo encontra-se ainda documentado numa inscrição lapidar daquela área: v. Albertos Firmat, M. ${ }^{a}$ L. e romero Carnicero, F., Una estela y otros hallazgos celtibéricos en Trehago (Soria), «Boletín del Seminario de Estudios de Arte y Arqueología», Valladolid, XLVII, 1981, p. 200-201.

(39) Tovar, A., Las inscripciones ibéricas y la lengua de los Celtíberos, «Boletín de la Real Academia Española», Madrid, XXV, 1946, p. 27-28; LeJeUne, M., op. cit. (v. nota 27), p. 50-51; UnTERManN, J., op. cit. (v. nota 7), p. 72; convém, no entanto, notar que a assimilação do $n$ também ocorre no 
*ca.t.n.i.pu.m. constituirá, portanto, a transliteração integral do topónimo, cujas transcrições para grego e latim seriam, respectivamente, *KavTVE,7T0i)v e *Cantnipo. Se a terminação em grego é o reflexo fiel do sufixo indígena, o tema em $n$ da transcrição latina poderá, talvez, dever-se ao facto de os geógrafos gregos terem precedido os latinos na transmissão da onomástica ibérica $\left({ }^{40}\right)$.

Este topónimo não sobreviveu um século à conquista romana do Sudoeste peninsular: em 45/44 a.G. deu lugar a Imperatoria Salaria, nome atribuído em honra de Sexto Pompeio $\left({ }^{41}\right)$.

Para além da conhecida emissão de asses com a cabeça de Neptuno no anverso $\left({ }^{42}\right)$ e o letreiro IMP-SAL no reverso entre dois golfinhos (43), comemorativa daquele evento, existe uma outra, de denários $\left({ }^{44}\right)$, também cunhada por Sexto Pompeio nesta cidade $\left({ }^{4 S}\right)$.

fenício-púnico e nas línguas semitas em geral: v. Solá-Solé, J. M., Acuñaciones monetárias de Olontigi, «Numisma», Madrid, 74, 1965, p. 20, nota 3.

$\left.{ }^{40}\right) \mathbf{J} \mathbf{A} \mathbf{0 в}$, P., Notes sur la toponymie grecque de la côte méditerranéenne de l'Espagne antique, «Ktèma», Strasbourg, 10, 1985, p. 268-271 ; Hoz, J. de, La escritura greco-ibérica, « Yeleia», Vitoria, 2-3, 1985-1986, p. 292.

(41) HÜвner, E., Corpus Inscriptionum Latinarum, II, Supplementum, Berlin, Georg Reimer, 1892, p. 802; Vasconcellos, J. L. de, Religiões da Lusitania, III, Lisboa, Imprensa Nacional, 1913, p. 172; Grant, M., From Imperium to Auctoritas, Cambridge, Cambridge University Press, 1969, p. 23, nota 1; Tovar, A., Iberische Landeskunde, II, 2 Lusitanien, Baden-Baden, Verlag Valentin Koerner, 1976, p. 214.

(42) A respeito da relação de Sexto Pompeio com Neptuno, comprovada na iconografia monetária, v. Grant, M., op. cit. (v. nota 41), p. 23, nota 1; Crawford, M. H., Roman Republican Coinage, Cambridge, Cambridge University Press, 1974, p. 495-496 e p. 739, nota 5; sobre uma emissão de semisses tipológica e cronologicamente afim das moedas em análise v. CH A VES Tristan, F., Las monedas hispano-romanas de Carteia, Barcelona, Asociación Numismática Española, 1979, p. 24, 99 e 139.

$\left.{ }^{43}\right)$ Foram igualmente cunhados semisses com a cabeça de Neptuno no anverso e um golfinho no reverso entre a legenda IMP SALAC: V. VIVES Y E SCUDER O, A., op. cit., (v. nota 16), est. LXXXIV, n. ${ }^{\circ} 11$.

(44) Crawford, M. H., op. cit., (v. nota 42), p. 486, n. 477.

(45) Grant, M., op. cit. (v. nota 41), p. 23, nota 1; Syme, R., Roman papers, I, Oxford, Clarendon Press, 1979, p. 364; os argumentos em favor da atribuição desta emissão a Salpensa apresentados por Buttrey, T. V., The «Pietas» denarii of Sextus Pompey, «The Numismatic Chronicle», London, 6th 
A primeira série desta emissão terá sido possivelmente cunhada ainda antes da introdução do novo topónimo, uma vez que este se encontra ausente da legenda do anverso $\left({ }^{46}\right)$. Nas séries seguintes, porém, já aparece representado pela abreviatura SAL $\left({ }^{47}\right)$. Daqui se infere a importância de que se reveste a cronologia desta emissão para datar a fundação de Salacia por Sexto Pompeio. Este terá adoptado o título IMP(erator), incluído na referida legenda, logo depois da morte do seu irmão Gneu, ocorrida na sequência da batalha de Munda ( $\left.{ }^{48}\right)$. Só um tal terminus post quem poderá explicar o emprego de vários cunhos até à inserção no mesmo letreiro do cognomen PIVS com que Sexto assinalou a morte de César $\left({ }^{49}\right)$. A introdução deste cognomen na titulatura do anverso poderá ter-se verificado já não em Salacia, mas algures no Sul da Península, palco das últimas batalhas de Sexto até à sua reconciliação com Lépido em Agosto ou Setembro de 44 a.C. $\left({ }^{50}\right)$. Por conseguinte, os últimos meses de 45 ou os primeiros de 44 afiguram-se-nos como a data mais provável para o início desta emissão que terá sido retomada por algumas semanas após os Idos de Março.

No tocante ao potamónimo pré-romano, apenas sabemos por Ptolemeu que ele perdurou para além do desaparecimento do topónimo que lhe deu origem ${ }^{(51)}$. Perdida gradualmente a memória deste último, ainda durante a época romana, o rio começou a ser

series, XX, 1960, p. 93-99, foram claramente refutados por Craw Ford, M. H., op. cit. (v. nota 42), p. 93-94, 480 e 486, sem, no entanto, ter deixado de secundar aquela atribuição.

(46) Craw Ford, M. H., op. cit. (v. nota 42), p. 486, n. ${ }^{\circ}$ 577/la.

I $^{4}$ ?) ID., ibid., p. 486, n. ${ }^{\circ} 477 / \mathrm{lb}-3 \mathrm{a}$.

(48) Grueber, H. A., Coins of the Roman Republic in the Rritish Museum, II, London, British Museum, 1910, p. 371 ; S y ме, K., op. cit. (v. nota 45), p. 369.

(49) ButTREy, T. V., op. cit. (v. nota 15), p. 92.

(50) Gaвba, E., Aspetti della lotta in Spagna di Sesto Pompeo, in «Legio VII Gemina», León, 1970, p. 153-154; os cunhos de anverso onde foi gravado o referido cognomen terão sido fabricados a partir de moedas anteriormente cunhadas em Salacia; sobre a utilização, ignorada por Buttery, de moedas como matrizes de novos cunhos v. García-Bellido. M. ${ }^{a}$ P., Las monedas de Cástulo con escritura indígena, Barcelona, Asociación Numismática Española, 1982, p. 220.

(51) Entretanto substituído por SocXXáxaa (Ptol. II, 5, 2). 
conhecido pelo nome de ${ }^{*}$ Salatus $\left({ }^{52}\right)$ (fluuius) ou *Salatum( $\left.{ }^{53}\right)$ (flumen). Conquanto a evolução *Salatu(s/m) $>*^{* S a l a d o}>$ *Saado > Sado não se encontre atestada documentalmente, conhece-se uma referência trecentista ao seu diminutivo aplicado inicialmente ao curso superior. «Ribeira de çaadam termo dalcacer» ${ }^{54}$ ). No decorrer do século xvi o mesmo diminutivo passou a designar a totalidade do rio, num claro testemunho do esquecimento a que a sua etimologia havia sido votada. Cremos que esta abusiva ampliação onomástica — rectificada a partir do século XVII com a reabilitação do potamónimo desprovido de sufixo (5S) - não deverá ser mais do que um efeito tardio do acentuado despovoamento das margens do Sado a jusante de Alcácer do Sal durante a Idade Média $\left({ }^{56}\right)$.

(52) Vasconcellos, J. L. de, Excursão archeologica a Alcacer-do-Sal, «O Archeologo Português», Lisboa, I, 1895, p. 84; Silve ira, J. da, Toponimia portuguesa, «Revista Lusitana», Lisboa, 24, 1922, p. 198.

(53) Du Cange, Glossarium Mediae et Infimae Latinitatis, Vil, Paris, Libraire des Sciences et des Arts, 1938, p. 280, s. u. Salata.

${ }^{(54)}$ Arquivo Nacional da Torre do Tombo, Chancelaria de D. João I, Liv. I, fl. $193 \mathrm{v}^{\circ}$ : carta de couto passada a Gonçalo Lourenço em 8 de Julho de 1388; sobre a junção do sufixo diminutivo -ão a Sado V. VAsconcellos, J. L. de, Excursão archeologica ao Sul de Portugal, «O Archeologo Português», Lisboa, IV, 1898, p. 114; ID.,Ementas gramaticais, «Revista Lusitana», Lisboa, 32, 1934, p. 281; Girão, A., Saneamento corogràfico e toponímico, «Boletim do Centro de Estudos Geográficos», Coimbra, 10-11, 1955, p. 91; Silveira, J. da e Girão, A., O mais antigo mapa de Portugal, «Boletim do Centro de Estudos Geográficos», Coimbra, 14-15, 1957, p. 26; quanto à sua utilização em nomes comuns v. Rio-Torto, G. M., Operações derivacionais que envolvem os sufixos -ão em português, in «Actas do 2. ${ }^{\circ}$ Encontro da Associação Portuguesa de Linguística (Lisboa, 1986)», Lisboa, 1987, p. 120-121 e p. 136-137, notas 41 e 42.

(55) Encontrámos pela primeira vez a forma Sado em Lẽ̃o, D. N. do, Descripção do Reino de Portugal, Lisboa, Jorge Rodriguez, 1610, f. 39.

(56) Azevedo, R. de, História da expansão portuguesa no Mundo, I, Lisboa, Ática, 1937, p. 61; RAu, V., A exploração e o comércio do Sal de Setúbal. Estudo de história económica, I, Bertrand, Lisboa, 1951, p. 67.

Conimbriga, 28 (1989), 71-99 
2. Legendas Latinas

Analisado o topónimo, debrucemo-nos mais detidamente sobre as legendas monetárias em latim, dignas da maior atenção sob o ponto de vista onomástico. Sem pretendermos realizar um estudo definitivo, as compreensíveis lacunas detectadas no volume I dos Monumenta Linguarum Hispanicarum do Professor Untermann impunham, quanto a nós, uma nova abordagem deste assunto. Atentemos por agora no quadro seguinte em que os letreiros surgem dispostos cronologicamente de acordo com a proposta de ordenação das emissões que apresentaremos a encerrar este trabalho.

\section{QUADRO I}

\begin{tabular}{|c|c|c|}
\hline \multirow{2}{*}{ Emissão } & \multicolumn{2}{|l|}{ LEGENDAS } \\
\hline & Anverso & Reverso \\
\hline II, 1 & ODACIS $\cdot A \cdot$ & \\
\hline II, 2 & $\mathrm{ODA} \cdot \mathrm{A} \cdot \mathrm{S} \cdot$ & \\
\hline III, 1a & CANDNIL $\cdot S I S C R \cdot F$ & \\
\hline III, $1 \mathrm{~b}$ & SISBE·SISCRA $\cdot F$ & \\
\hline III, 2 & CANDNIL & $\mathrm{SISBE} \cdot \mathrm{A} \cdot \mathrm{S}$ \\
\hline IV & SISVGVRHIL & \\
\hline $\mathrm{V}$ & CANTNIP $\cdot[$ EDNI?] $/ \overline{\mathrm{AE}} \cdot \mathbf{F}$ & \\
\hline VI & ANDVGEP·SISVC $\cdot F \cdot /$ TVL & \\
\hline VII & $\operatorname{COR}[\overline{\mathrm{AN}} \mathrm{I} ?]$ & \\
\hline
\end{tabular}

Se exceptuarmos o último antropònimo registado - ainda assim, de leitura duvidosa - todos os nomes de magistrados presentes nos numismas de ${ }^{*}$ Cantnipo são desconhecidos no resto da Península.

Ao primeiro deles, Odacis, alguns autores atribuem uma origem indo-europeia, havendo quem o identifique com Audax, um dos 
assassinos de Viriato ( $\left.{ }^{57}\right)$. A não ser que se trate de um improvável genitivo, a terminação em -is parece inviabilizar uma tal teoria. Preferimos subscrever a opinião de Untermann — ainda que baseada numa leitura deficiente (Odacisa) — no sentido de conferir a este nome um parentesco com a onomástica não indo-europeia da Bética ${ }^{58}$ ). Otati, nome de um magistrado monetário de Ipolca, é o que apresenta maiores semelhanças, não deixando Untermann de apontar outros possíveis paralelos, tais como Optatus, Otacilius e o topónimo Oducia $\left(^{(59)}\right.$. Segundo o investigador alemão, Optatus e Otacilius, nomes marcadamente latinos, poderão mascarar um nome indígena como Odacis, foneticamente semelhante.

A abreviatura A., associada ao nome do magistrado, continua à espera de decifração. $\mathrm{O}$ seu desdobramento em $\mathrm{A}$ (edilis), ainda que possível $\left({ }^{60}\right)$, é difícil de sustentar tanto mais que em duas séries de semisses, uma das quais pertencente à mesma emissão de Odacis, esta sigla vem acompanhada por um S., igualmente inexplicável. $\mathrm{Na}$ outra série de semisses lê-se a expressão SISBE-A-S- à qual estaríamos tentados a atribuir um significado, em língua indígena, equivalente a SISBE-SISCRA-F ( ${ }^{61}$ ), fórmula onomástica latina que

$\left.{ }^{57}\right)$ Heiss, A., Description générale des monnaies antiques de VEspagne, Paris, Imprimerie Nationale, 1870, p. 414; HoLder, A., Alt-celtischer Sprachschatz, II, Leipzig, B. G. Teubner, 1904, col. 834, s. u. Odax; PaLомa R LAPESA, H., La onomástica personal pre-latina de la antigua Lusitania, Salamanca, Universidad de Salamanca, 1957, p. 88, s. u. Odacis.

(58) Untermann, J., op. cit. (v. nota 7), p. 343-344.

(59) Id., ibid., p. 338 e 344; v. igualmente Gorrochategui GHurruca, J., op. cit. (v. nota 18), p. 243-244.

(60) González Román, G., Imperialismo y Romanización en la Provincia Hispania Ulterior, Granada, Universidad de Granada, 1981, p. 209; LACorT Navarro, P. J. et allí, Nuevas inscripciones latinas de Córdoba y su provincia, «Faventia», Barcelona, 8/1, 1986, p. 74-75; Marín Díaz, M. A., Emigración, colonización y municipalización en la Hispania republicana, Granada, Universidad de Granada, 1988, p. 231-232.

(61) Neste caso, A. poderia abreviar o termo ibérico (em caracteres latinos) equivalente a filius: V. UNTERMANN, J., Inscripciones sepulcrales ibéricas, «Cuadernos de Prehistoria y Arqueologia Castellonenses», Castellón de la Plana, 10, 1984, p 113; contra, Siles, J., Sobre la epigrafia ibérica, in «Epigrafía de Época Romano-Republicana», Zaragoza, Institución Fernando el Católico, 1986, p. 40-42. 
se encontra inscrita nos asses correspondentes. Por ser hipótese demasiado arrojada, julgamos preferível deixar a sua discussão para outra oportunidade.

A emissão III é da responsabilidade de dois irmãos, Candnil e Sisbe, filhos de Sisera. Quando abordámos a questão relativa ao topónimo, havíamos relacionado Candnil com o cognomen Cantnec... de uma epígrafe de Antequera (62). É interessante notar que sendo M. Sempronius Cantnec... filho de M. Sempronius Sisanna, a transmissão dos nomes indígenas é idêntica àquela que se observa na legenda em apreço, isto é, a um nome iniciado pelo segmento Sissucede um outro começado por Cantn-. O mesmo não acontece com o nome Sisbe, que compartilha com o patronímico a sílaba inicial. Também na antroponimia ibérica da Citerior, mormente na da turma Salluitana, conhecem-se vários casos em que um elemento do patronímico faz parte do nome do descendente directo (63). Sisbe e Sisera vêm assim juntar-se à lista de nomes pessoais iniciados por Sis-, com vários testemunhos no vale do Baetis, embora estes últimos se caracterizem, com uma possível excepção ${ }^{64}$ ), pela presença de uma vogal após o elemento inicial $\left(6 \mathrm{~S}^{*}\right)$. Como eventuais paralelos para Sisera, Untermann indica ainda os antropónimos formados pelo radical iscer(bb). Recordemos entretanto que estes ocorrem quase exclusivamente na Citerior $\left({ }^{67}\right)$, ou seja, numa área onde não se conhecem nomes pessoais com a componente Sis-. Com Sisbe a situação é idêntica: torna-se aventurado aparentá-lo

(62) V. nota 21.

(63) Palomar lapesa, M., op. cit. (v. nota 20), p. 368; Untermann, J., La lengua ibérica, «Varia», Valencia, III, 1984, p. 256-257.

(64) Numa moeda de Vesci: v. Vives y Escudero, A., op. cit. (v. nota 16), Est. XCI, n. ${ }^{\circ} 3$.

${ }^{\left({ }^{65}\right)}$ Untermann, J., Elementos de un atlas antroponimico de la Hispania Antigua, Madrid, Consejo Superior de Investigaciones Científicas, 1965, p. 22 e p. 163 , mapa 70 .

(6ö) Untermann, J., op. cit. (v. nota 7), p. 344.

(67) UntermanN, J., op. cit. (v. nota 65), p. 22 e p. 117, mapa 45; ID., Repertorio antroponimico ibérico, "Archivo de Prehistoria Levantina», Valencia, XVII, 1987, p. 303. 
simultaneamente com os nomes em Sis- e com três presumíveis antropónimos desconhecidos na Ulterior: Isbatar(is) (Sagunto) ${ }^{68}$ ), Isbetar(licer) (Sagunto) $\left({ }^{69}\right.$ ) e Isbinai (La Serreta, Alcoy) $\left({ }^{70}\right)$.

O segmento Sis-, desta vez seguido de vogal, repete-se em Sisucurhil, nome do magistrado encarregado da emissão IV. Tal como o elemento Sisuc- é susceptível de ser relacionado com antropónimos meridionais, também -urhil apresenta afinidades com aqueles, em particular com Vrchail, nome que evidencia igualmente marcas de aspiração $\left({ }^{71}\right)$.

Cantnip. é o nome do responsável pela emissão V. Conquanto este seja facilmente legível, o mau estado de conservação dos numismas pertencentes a esta emissão não nos permitiu interpretar com segurança o resto da legenda. [EDNI ?]/AE*F é a leitura que propomos $\left({ }^{72}\right)$, se bem que, em face das incertezas, possam ser aventadas outras interpretações como, por exemplo, [EONI?]/ $/ \tilde{\mathrm{A}} \hat{\mathrm{E}} * \mathrm{~F}\left({ }^{73}\right)$.

Igualmente digno do maior interesse é o letreiro da emissão VI. O nome Andugep. comporta duas raízes, conhecendo-se na Península vários nomes pessoais em que a primeira está presente. Entre eles

(68) Palomar lapesa, H., op. cit. (v. nota 20), p. 382-383; Siles, J., op. cit. (v. nota 5), p. 248, n. ${ }^{\circ}$ 1062; Untermann, J., La gramática de los plomos ibéricos, «Veleia», Vitoria, 2-3, 1985-1986, p. 50, nota 47; Siles, J., op. cit., (v. nota 61), p. 37-40.

(69) Palomar lapesa, H., op. cit. (v. nota 20), p. 382-383; UntermanN J., op. cit. (v. nota 20), p. 63; Siles, J., op. cit. (v. nota 5), p. 249, n. ${ }^{\circ} 1063$; Untermann, J., op. cit., (v. nota 68), p. 50; Siles, J., op. cit., (v. nota 61), p. $37-40$.

(70) Siles, J., op. cit. (v. nota 5), p. 249, n. 1064.

${ }^{(71)}$ AlBERTOS M. ${ }^{a}$ L., Las aspiradas en las lenguas paleohispànie as: la $F$ y $G$, «Veleia», Vitoria, 2-3, 1985-1986.

(72) Ednoum (Peñalba de Villastar): v. Tovar, A., op. cit. (v. nota 39), p. 35; Lejeune, M., op. cit. (v. nota 27), p. 29; Hoz, J. de e Michelena, L., La inscripción celtibérica de Botorrita, Salamanca, Universidad de Salamanca, 1974, p. 50 e p. 77 , nota 5.

(73) Eona (Peñalba de Villastar) : v. LEJEUne, M., op. cit. (v. nota 27), p. 81; v. ainda os nomes aquitanos Edunnis (gen., mase.) e Aedunniae (dat., fern.) : Gorrochategui GhurRuca, J., op. cit. (v. nota 18), p. 280. 
poderemos citar Andotus ( $\left.{ }^{74}\right)$, Antu( $\left.{ }^{75}\right)$, Antor $\left({ }^{76}\right)$, Antubellicus $\left({ }^{77}\right)$, Andumobios $\left({ }^{78}\right)$ e Aftdos $\left({ }^{79}\right)$. Este último encontra-se também atestado na Aquitânia $\left({ }^{80}\right)$ a par de outros nomes como Andoston $\left({ }^{81}\right)$ e Andossus ( ${ }^{82}$ ). Antullus é um cognomen latino que, segundo Untermann, se poderá relacionar com os nomes acima enunciados $\left({ }^{83}\right)$, apesar de estar concentrado na Bética, onde aqueles não se encontram referenciados. Em trabalho recente, o mesmo autor inclui-o entre os antropónimos característicos do Sudoeste, ao lado de Attenius, Attinius e Broccus, bem como dos que começam pelo segmento Sis-: Sisiren, Siseanba, etc. $\left({ }^{84}\right)$.

A raiz -gep- é bastante mais rara; Kebes (EI Cigarralejo) $\left({ }^{8 \mathrm{~S}}\right)$, $S$ or seitei ceboi (Ampurias) ${ }^{(86)}$, Boftoloicebobam (Ullastret) $\left({ }^{87}\right)$ e Binicebin (Alcoy) ${ }^{88}$ ) são quatro possíveis antropónimos onde ela parece estar contida.

(74) Albertos, M. ${ }^{\text {a }}$ L., La onomástica personal indigena de la región septentrional, leia», Vitoria, 2-3, 1985-1986, p. 162.

${ }^{(75)}$ Siles, J., op. cit. (v. nota 5), p. 58, n. ${ }^{\circ} 152$.

(76) ID., ibid., p. 58, n. ${ }^{\circ} 151$.

(77) Palomar lapesa, H., op. cit. (v. nota 57), p. 35-36; Encarnação, J. d', Inscrições romanas do conventus Pacensis, Coimbra, Instituto de Arqueologia da Faculdade de Letras, p. 567, n. ${ }^{\circ} 487$ e p. 777.

(78) Siles, J., op. cit. (v. nota 5), p. 58.

(79) García Merino, e. e Albertos firmat, M.a L., Una nueva tessera hospitalis con texto en lengua celtibérica, hallada en Vxama (Soria), in «Actas del III Coloquio sobre Lenguas y Culturas Paleohispánicas (Lisboa, 1980)», Salamanca, Universidad de Salamanca, 1985, p. 316.

( ${ }^{80}$ ) Gorrochategui Churruca, J., op. cit. (v. nota 18), p. 142-143.

(si) ID., ibid., p. 141-142.

(82j ID., ibid., p. 136-140 e 359.

(83) Untermann, J., op. cit. (v. nota 65), p. 57, mapa 9.

$\left.{ }^{84}\right) \quad$ ID., Lenguas y unidades políticas del Suroeste hispánico en época prerromana, sep. de «De Tartessos a Cervantes», Köln-Wien, Böhlau Verlag, 1985 , p. 4 e p. 7 , mapa 4.

${ }^{85}$ ) Siles, J., op. cit. (v. nota 5), p. 159, n. ${ }^{\circ} 619$.

${ }^{(8)}$ ID., ibid., p. 301, n. ${ }^{\circ} 1345$.

$\left({ }^{87} \mathbf{j}\right.$ ID., ibid., p. $\mathbf{1 4 2}, \mathbf{n} .^{\circ} 534$.

(88) PéRez BOJAS, M., La estela ibérica de Caspe: introducción a su estudio lingüístico, «Archivo Español de Arqueología», Madrid, 56, 1983, p. 280. V. outros possíveis exemplos em bonet rosado, H. e Mata Parreño, C., Nuevos grafitos e inscripciones ibéricos valencianos, "Archivo de Prehistoria Levantina», Valencia, XIX, 1989, p. 138-139 e 141. 
Pelo patronímico, ainda que abreviado, sabemos que Andugep. é filho do magistrado responsável pela emissão IV. Esta não é a única relação familiar atestada entre os magistrados monetários de *Cantnipo, já que, como vimos, os dois magistrados referidos na emissão III eram irmãos. Estes laços familiares entre membros da aristocracia ainda não romanizada onomasticamente poderão constituir um resquício do carácter hereditário dos cargos de chefia nas cidades ibéricas $\left({ }^{89}\right)$.

Apenas duas hipóteses se nos colocam com vista à interpretação da abreviatura Tul. que encerra a fórmula onomástica: ou estamos perante uma forma adjectival composta a partir de um topónimo expressando a origo do magistrado, ou então, perante um genitivo do plural mencionado uma unidade supra-familiar, talvez de natureza tribal. Isurgut. (Arva e Carmona) $\left({ }^{90}\right)$ e Chilasurgun. (Alcalá del Rio) $\left({ }^{91}\right)$ são outras comunidades de provável origem não indo-europeia, que ficaram registadas na epigrafia. É lícito crer que a eventual tribo cujo nome é abreviado por Tul. se localize ou até coincida com o território de ${ }^{*}$ Cantnipo.

Quanto à hipótese (a nosso ver, mais remota) de que Tul. abrevie um adjectivo mencionando a origo pessoal, é necessário ter-se presente que na toponímia hispânica o leque de opções é bastante reduzido. Somente Tullica, cidade dos Caristos ( ${ }^{92}$ ), e Tullonium, cidade dos Várdulos $\left({ }^{93}\right)$, ambas no Nordeste da Península, podem esclarecer a abreviatura. O principal óbice à aceitação de qualquer um destes topónimos reside no facto de eles pertencerem a um território que dificilmente seria o berço de um nome pessoal como Sisuc., sem paralelo na onomástica daquela área.

(89) Étienne, R., Le culte impérial dans la Péninsule Ibérique d'Auguste à Dioclétien, Paris, E. de Boccard, 1958, p. 51-52; González Roman, C., op. cit. (y. nota 60), p. 17-18.

(90) SÁez Fernández, P., Las centurias de la Bética, «Habis», Sevilla, 9, 1978 , p. 265.

(91) HüBNER, E., op. cit. (v. nota 17), p. 143, n. ${ }^{\circ} 1087$.

(92) Al ве rtos, M.a L., Alava prerromana y romana. Estudio lingüístico ${ }_{i}$ «Estudios de Arqueología Alavesa», Vitoria, IV, 1970, p. 172.

(93) EAD., ibid., p. 172. 
Resta-nos comentar o nome de um magistrado que deve constituir a única excepção à origem hispânica dos nomes pessoais aqui analisados. Trata-se de Corani(us) (94), nome eventualmente representado numa série de semisses de que não vimos qualquer exemplar. É, pois, com as necessárias reservas que apresentamos esta leitura. Para além do caso aqui apontado - estranhamente desprovido de praenomen - conhecem-se outros em Manique de Baixo (Cascais, Lisboa) ( ${ }^{95}$ ), Herdade da Amendoeira (Neves, Beja) $\left({ }^{96}\right)$, Alcolea del Rio (Sevilha) ${ }^{97}$ ), La Rambla (Córdoba) $\left({ }^{98}{ }^{*}\right.$ ) e em moedas de Valentia ("). Tal como em *Cantnipo, os dois últimos nomina identificam magistrados da época republicana. A presença de indivíduos portadores deste e doutros nomina de origem itálica numa fase algo incipiente da romanização deixa entrever a possibilidade de se tratar de imigrantes ou filhos de imigrantes provenientes daquela área, que haviam previamente cumprido o serviço militar na Hispânia $\left({ }^{10}\right)$. Atraídos quer pela fertilidade dos vales fluviais do Sul, quer pela prosperidade comercial dos centros urbanos do Litoral, aí se instalaram, tomando no espaço de uma ou duas gerações o lugar das elites locais no desempenho de várias magistraturas. Semelhante fenómeno ter-se-á também verificado em *Cantnipo e noutras cidades do Ocidente, pesando decisivamente na concessão a algumas delas do direito latino, em época anterior a Augusto (101).

(94) Rodríguez de Berlanga, M., Varna, in «Nuevo método de clasificación de las medallas autónomas de España», II, Sevilla, 1873, p. 372; VIVES Y ESCUDERo, A., op. cit. (v. nota 16), est. LXXXIV, n. ${ }^{\circ} 8$.

(95) Hü BNER, E., op. cit. (v. nota 17), p. 694, n. ${ }^{\circ} 5000$.

(96) ENCARNAÇ̃̃o, J. d', op. cit. (v. nota 77), p. 378-380, n. ${ }^{\circ} 306$.

(97) Hü BNer, E., op. cit. (v. nota 17), p. 139, n. ${ }^{\circ} 1060$.

(98) Lacort Navarro, P. J. et alii, op. cit. (v. nota 60), 73-74.

(") PENA, M. a J., Los magistrados monetales de Valentia, «Saguntum», Valencia, 20,1986, p. 155-156.

(100) González Román, G., op. cit. (v. nota 60), p. 196; Pena, M. ${ }^{a}$ J., op. cit. (v. nota 99), p. 160-163; Richardson, J. S., Hispaniae. Spain and the development of Roman imperialism 218-82 BC, Cambridge, Cambridge University Press, 1986, p. 162-164; Marín Díaz, M. A., op. cit. (v. nota 60), p. 47-82.

(101) LE Roux, P., Municipe et droit latin en Hispania sous VEmpire, «Revue Historique de Droit Français et Étranger», Paris, 64, 1986, p. 335-340. 


\section{Tipologia}

À semelhança do que tem acontecido com a antroponimia, a tipologia das moedas de *Cantnipo tem sido votada ao esquecimento em diversos trabalhos relativos à numismática ibero-romana. Sendo essas obras da autoria de investigadores espanhóis, uma tal indiferença explica-se, por um lado, pela situação em que se encontra a numismática em Portugal (102) e, por outro, pela raridade dos achados feitos em território espanhol, o que parece constituir um indício da circulação local da numária em apreço. Porém, o quadro seguinte mostra-nos que os tipos comummente referidos não correspondem em número e em variedade aos que foram até agora identificados.

QUADRO II

\begin{tabular}{|c|c|c|}
\hline \multirow{2}{*}{ Emissão } & \multicolumn{2}{|c|}{ TIPOS } \\
\hline & Anverso & Reverso \\
\hline $\mathrm{I}, 1$ & Cabeça de Hércules & Dois atuns \\
\hline $\mathrm{I}, 2$ & Duas espigas & Hipocampo \\
\hline II, 1 & Cabeça de Hércules & Dois atuns \\
\hline II, 2 & Cabeça de Neptuno & Atum \\
\hline III, la & Cabeça de Júpiter & Dois atuns \\
\hline III, $1 \mathrm{~b}$ & Cabeça de Júpiter & Dois atuns \\
\hline III, 2 & Cabeça de Hércules & Atum \\
\hline IV & Cabeça de Neptuno & Dois golfinhos \\
\hline V & Cabeça de Hércules & Dois golfinhos \\
\hline VI & Cabeça de Hércules & Dois golfinhos \\
\hline VII & Cabeça de Hércules & Skyphos(?) \\
\hline VIII, 1 & Cabeça de Hércules & Dois golfinhos \\
\hline VIII, 2 & Espiga & Golfinho \\
\hline
\end{tabular}

(102) Marques, M. G., História, numismática e coleccionismo, «Numisma», Lisboa, 38, 1985, p. 1-3. 
Importa desde já ter presente que todos os numismas em análise foram emitidos sob a autoridade romana (103) e que os tipos que eles veiculam com maior destaque - nomeadamente as figuras de Hércules, Júpiter e Neptuno - são passíveis de reflectir as crenças religiosas dos conquistadores. No entanto, as efígies dos dois primeiros admitem outras interpretações que variam de acordo com a religião dos utilizadores/destinatários. Assim, e dada a relevância dos influxos fenício-púnicos em *Cantnipo $\left({ }^{104}\right)$, é de admitir que, num paralelismo com a iconografia monetária gaditana, a figura de Hércules represente Melkart, podendo Baal Hammon ter sido assimilado às feições de Júpiter-Saturno. Possivelmente instaurado por comerciantes fenícios e cartagineses durante as primeiras viagens ao extremo Ocidente da Península (10S), o culto a Melkart e a Baal Hammon viria a estender-se às populações autóctones que raras vezes se mostraram refractárias a inovações de índole religiosa (106). A existência, nesta cidade, de um santuário pré-romano $\left({ }^{107}\right)$ semelhante a outros localizados no Sudeste da

(103) Beltrán Lloris, F., Sobre la función de la moneda ibérica e hispano-romana, in «Estudios en homenaje al Dr. Antonio Beltrán Martínez», Zaragoza, Universidad de Zaragoza, 1986, p. 890 e 899; Burnetr, A., The changing face of Republican numismatics, «The Journal of Roman Studies», London, LXXVII, 1987, p. 179.

(104) Silva, G. T. da, et alii, Escavações arqueológicas no castelo de Alcácer do Sal (campanha de 1979), «Setúbal Arqueológica», Setúbal, VI-VII, 1980-81, p. 210-213; Edmondson, J. C., Two industries of Roman Lusitania. Mining and garum production, Oxford, British Archaeological Reports, 1987, p. 107.

$\left.{ }^{105}\right)$ Ribichini, S., Reliefs and religious life, in «The Phoenicians. Under the scientific direction of Sabatino Moscati», Milano, Bompiani, 1988, p. 114 e 118 .

(106) Blázquez, J. M., El sincretismo en la Hispania romana entre las religiones indígenas, griega, romana y mistéricas, in «La Religión Romana en Hispania», Madrid, Ministerio de Cultura, 1981, p. 179; esta aculturação religiosa tem sido recentemente posta em causa: v. p. ex., BELÉn, M., Importaciones fenicias en Andalucía Occidental, in «Los Fenicios en la Península Ibérica», II, Barcelona, Editorial Ausa, 1986, p. 274-275.

$\left({ }^{107}\right)$ Comprovada pelo achado de mais de uma dezena de estatuetas de bronze representando orantes: v. VASCONCELlos, J. L. de, op. cit. (v. nota 52), p. 79-80; Ferreira, O. da V. e Silva, C. T. da, Estatueta lusitana (?) de bronze

Conimbriga, 28 (1989), 71-99 
Península $\left({ }^{108}\right)$ constitui o principal testemunho dessa religiosidade de origem semita. Tal como nas amoedações de Gadir/Gades e de $\operatorname{Sexs}\left\{{ }^{109}\right)$, outra cidade de fundação fenícia, nas primeiras emissões, Hércules-Melkart surge acompanhado por dois atuns no reverso, simbolizando o estatuto de deus protector dos navegadores $\mathrm{e}$ comerciantes $\left({ }^{11^{\circ}}\right)$. Mas não é só a numismática que nos informa da presença no Ocidente do culto a Melkart enquanto divindade marinha. Também na Geografia de Estrabão (III, 1, 4) se recolhe uma referência, ainda que obscura, a um templo consagrado a Héracles-Melkart junto ao cabo de S. Vicente (111).

A iconografia gaditana será retomada em várias emissões até ser substituída por uma cabeça de Hércules, imberbe, desprovida de pele de leão, mas com um diadema de louros (112). Esta diferente representação de Hércules parece significar um corte com o mundo semita simbolizado pela anterior efíge conotada com Melkart, traduzindo uma modificação na vivência religiosa da população indígena no sentido de uma total conversão aos deuses do panteão romano e às práticas religiosas que uma tal atitude acarretava.

A presença de Júpiter-Baal Hammon na numária de *Cantnipo é bastante mais fugaz, apenas ocorrendo numa emissão (113).

de Alferrar (Setúbal), «Revista de Guimarães», Guimarães, LXXX, 1970, p. 101 । Gomes, M. V., El «smiting god» de Azougada (Moura), «Trabajos de Prehistoria»»» Madrid, 40, 1983, p. 208.

(108) ID., ibid., p. 208.

${ }^{(109)}$ Villaronga, L., op. cit. (v. nota 10), p. 161, n. ${ }^{\circ} 427$.

(no) Sold̀-Solé, J. M., Miscelánea púnico-hispana, «Sefarad», Madrid, XVI, 1956, p. 342-343; García Y Bellido, A., Deidades semitas en la España Antigua, «Sefarad», Madrid, XXIV, 1964, p. 15-16 e 28; Chaves Tristán, F., op. cit. (v. nota 42), p. 22-23; García-Bellido, M. ${ }^{\text {a }}$., op. cit. (v. nota 14), p. $509-510$.

( $\left.{ }^{\mathrm{m}}\right)$ Vasconcellos, J. L. de, Religiões da Lusitania, II, Lisboa, Imprensa Nacional, 1905, p. 200-202; SAlinas de Frías, M., El «Hieron Akroterion» y la geografia religiosa del extremo occidente según Estrabón, in «Actas $1 .^{\circ}$ Congreso Peninsular de Historia Antigua (Santiago de Compostela, 1986)», Universidad de Santiago de Compostela, II, 1988, p. 139-142.

(112) Vives Y Escudero, A., op. cit. (v. nota 16), est. LXXXIV, n. ${ }^{\circ}$ 5; Chaves Tristán, F. e Marín Ceballos, M. ${ }^{a}$ C., Numismática y religión romana en Hispania, in «La Religión Romana en Hispania», Madrid, Ministerio de Cultura, 1981, p. 37.

(113) V. infra, moedas n.os 10-12. 
O carácter orientalizante do deus é comprovado pela existência de dois peixes nos cunhos de reverso, atestando a qualidade de Baal Hammon como protector dos mercadores fenícios e cartagineses que demandavam por mar os centros urbanos do Litoral oeste da Península $\left({ }^{114}\right)$. Não é, por isso, de estranhar que o mesmo deus identificado com Saturno/Júpiter pelas populações semitas romanizadas do Norte de África (11S) — tenha encontrado um outro local de culto no Promontorio de Sagres a que alude Avieno na Ora Maritima (vv. 215-216) (116).

É de admitir que outros tipos documentados na numária em apreço, tais como espigas, golfinhos e símbolos astrais, estivessem imbuídos de um significado religioso. M. ${ }^{a}$ P. García-Bellido, no supracitado estudo dedicado às emissões «líbio-fenícias», confere a este elementos tipológicos a categoria de atributos da deusa Tanit $\left({ }^{117}\right)$.

No que toca à presença de Neptuno, não é de excluir a priori a interpretatio romana de uma divindade semita de cariz marinho e de nome ainda desconhecido (118). Porém, não se conhecem na Península Ibérica quaisquer provas de um culto pré-romano a um deus com tais características. Ao contrário do que sucede nas emissões de denários republicanos com a efíge de Neptuno (119), nas moedas em análise, este é representado imberbe, o que parece

(114) BLECH, M., Saturn in Hispanien, «Madrider Mitteilungen», Mainz am Rhein, XIX, 1978, p. 247-248; Riв Iс нini, S., op. cit. (v. nota 105), p. 114.

(115) Blech, M., op. cit. (v. nota 114), p. 240-247; Chayes Tristán, F., op. cit. (v. nota 42), p. 18; García-BELlido, M. ${ }^{\text {a }}$., op. cit. (v. nota 14), p. 508.

(116) Vasconcellos, J. L. de, op. cit. (v. nota 111), p. 213-214; García Y BELLIDO, Á., op. cit. (v. nota 110), p. 37.

(117) García-Bellido, M. ${ }^{\text {a }}$ P., op. cit. (v. nota 14), p. 509-510 e p. 5120 nota $64 ; \mathrm{v}$. igualmente FANTAR, M. H., La mer dans la mythologie et $V$ iconographie des Phéniciens-P uniques, «Africa», Tunis, III-IV, 1969-79, p. 63-66.

(118) ID., Le dieu de la mer chez les Phéniciens et les Puniques, Roma, Consiglio Nazionale delle Ricerche, 1977, passim; Trebl, B. L., The influence of the Near East on the Punic world - the numismatic evidence, «Les Cahiers de Tunisie», Tunis, 117-118,1981, p. 486.

${ }^{(19)}$ ZEHNACKER, H., Moneta. Recherches sur Vorganisation et Vart des émissions monétaires de la République romaine (289-31 av. J.-C.), Rome, École Française de Rome, 1973, p. 732-733. 
denunciar a formação local dos scalptores envolvidos. Tal como numa inscrição de Bobadela $\left({ }^{12 \circ}\right)$, Neptuno reveste aqui uma natureza marcadamente fluvial, à imagem do que se verifica em diversas províncias do Império ( $\left.{ }^{121}\right)$. Porém, enquanto deus dos mares, Neptuno foi adorado num templo erguido em local não muito distante, no Outão, na margem norte da foz do Sado (122). Os últimos vestígios deste templo - já existente no século I d.C. (123) e presumivelmente referenciado por Estrabão (III, 3, 1) ${ }^{(124)}$ - terão sido arrasados aquando da realização de obras numa fortaleza em meados do século XVII $\left({ }^{125}\right)$. Fica por determinar a existência de qualquer conexão entre este santuário e as moedas de *Cantnipo com a efige de Neptuno, ou mesmo entre estas e as moedas com a legenda IMP-SAL, que reproduzem as feições daquele deus de acordo com a iconografia clássica.

O hipocampo é outro dos tipos utilizados que é susceptível de ser relacionado com Posídon/Neptuno. Com efeito, eram os hipocampos que, segundo a mitologia clássica, puxavam o carro do deus dos mares $\left({ }^{126}\right)$. No entanto, já no $2 .^{\circ}$ milénio, estes animais

(120) Ribeiro, J. C., Estudos histórico-epigráficos em torno da figura de L. Iulius Maelo Caudicus, «Sintria», Sintra, I-II (1), 1982/83, p. 199 e p.430, nota 29.

(121) Durrach, F., Neptunus, in «Dictionnaire des Antiquités Grecques et Romaines», IV, 1, Paris, Hachette, s. d., p. 61, 71-72; Toutain, J., Les cultes païens dans VEmpire romain, I, Paris, Ernest Leroux, 1907, p. 372-378; Vasconcellos, J. L. de, op. cit. (v. nota 41), p. 251 ; Ben BaAziz, S., Neptune, dieu «guérisseur», in "Actes du Troisième Congrès International d'Études des Cultures de la Méditerranée Occidentale (Jerba, «Avril 1981)», Tunis, 1985, p. 425-436.

(122) Silva, C. T. da e So a res, J., Arqueologia da Arrábida, Lisboa, Serviço Nacional de Parques, Reservas e Conservação da Natureza, 1986, p. 198; Alarcã o, J. de, Roman Portugal, /, Introduction, Warminster, Aris \& Phillips Ltd, 1988, p. 102.

(123) Silva, C. T. da e Soares, J., op. cit. (v. nota 122), p. 199.

(124) Alarcĩo, J. de, op. cit. (v. nota 122), p. 147, nota 80.

(125) Silva, C. T. da e Soares, J., op. cit. (v. nota 122), p. 198; sobre a etimologia de Outão v. MaChado, J. P., Dicionário onomástico etimológico da lingua portuguesa, III, Lisboa. Confluência, [1984], p. 1109.

(126) V., p. ex., Lame R, H., Hippokampos, in «Paulys Real-Encyclopädie der classischen Altertumswissenschaft», Vili (16), Stuttgart, J. B. Metzlerche Buchhandlung, 1913, cols. 1748-1772; Riсн те R, G. M. A., Engraved gems of 
fabulosos surgem associados ao deus ugarítico $\operatorname{Yam}\left({ }^{127}\right)$, sendo, nos inícios do milénio seguinte, completamente integrados na religião fenício-púnica ${ }^{128}$ ). Tal facto explica a existência, no Sul da Ibéria, de alguns testemunhos iconográficos a eles respeitantes $(129)$.

O skyphos dentro de láurea, presumivelmente representado no reverso de um raríssimo divisor, deverá ser relacionado com o culto a Hércules, cuja efígie surge uma vez mais reproduzida no anverso $\left(1^{\circ}\right)$.

\section{Cronologia}

Quanto à cronologia das moedas de ${ }^{*}$ Cantnipo, pouco haverá a dizer. Os argumentos de base metrológica tendentes a atribuir datações relativas e absolutas às emissões hispânicas de bronze têm demonstrado alguma falta de solidez $\left({ }^{131}\right)$. Não é de descartar a eventualidade de que um aturado estudo dos cunhos venha a permitir estabelecer a sequência exacta das emissões, ainda que, numa análise superficial, não tenhamos encontrado qualquer ligação de cunhos de reverso entre moedas de emissões diferentes. Até que sui ja algum achado rigorosamente datável deveremos continuar a situar o funcionamento da ceca de *Cantnipo na $2{ }^{\text {a }}$ metade do século II a.C. e na primeira do século seguinte.

the Romans, London, Phaidon, 1971, p. 30; Crawford, M. H., op. cit. (v. nota 42), p. 410-411, n. 399.

(127) TreLL, B. L., op. cit. (v. nota 118), p. 487, nota 44.

(128) Fantar, M. H., op. cit. (v. nota 117), p. 61-62; Blázquez, J. M., Primitivas religiones ibéricas, Madrid, Ediciones Cristiandad, 1983, p. 147.

${ }^{(129)}$ ID., ibid., p. 149; MaI A, M. G. P., Neves I l e a «faciès» cultural de Neves-Corvo, «Arquivo de Beja», Beja, 2. ${ }^{\text {a }}$ série, III, 1986, p. 36.

(130) Vives y ESCUdero, A., op. cit. (v. nota 16), est. LXXXIV, n. ${ }^{\circ} 8$; Atencia Páez, R. e Beltrán fortes, J., Sobre el culto de Hércules en la Baetica: a propósito de un ara votiva de Mollina [Málaga), «Mainake», Málaga, X, 1988, p. 130-134.

(131) Grant, M., op. cit. (v. nota 41), p. 300; Crawford, M. H., op. cit. (v. nota 11), p. 91; Richardson, J. S., op. cit. (v. nota 100), p. 121-122, nota 132; KNAPP, R. C., Spain, in "The coinage of the Roman world in the Late Republic», Oxford, British Archaeological Reports, 1987, p. 19 e p. 31, notas 1,2 e 3 . 


\section{Ordenação das emissões}

No catálogo que a seguir apresentamos, procurámos ordenar as emissões cronologicamente, baseando-nos no critério tipològico e tomando como pontos de referência quer os protótipos gaditanos, quer a emissão de asses de Imperatoria Salaria.

A ordenação que propomos segue de perto a que foi apresentada por Vives (132). Parece-nos, contudo, que, pelo facto de apresentar o anveso anepígrafo, dever-se-á colocar a emissão com a cabeça de Hércules imberbe $\left({ }^{133}\right)$ no fim da seriação.

Desta nossa proposta constam várias emissões que foram ignoradas por Vives, a despeito de algumas delas já terem sido anteriormente publicadas. Podemos citar como exemplo a relativamente numerosa série de divisores com duas espigas no anverso e um hipocampo sobre a legenda ibérica no reverso, incluída por Vives nas moedas incertas $\left({ }^{134}\right)$. Esta decisão resultou certamente do facto de este eminente numismata ter examinado somente moedas contramarcadas com um S sobre a legenda indígena ou com esta intencionalmente raspada. A supressão desta legenda e a consequente aplicação do S - desdobrável em Salada - visou prolongar a circulação daqueles numismas após a alteração do topónimo, numa altura em que o abastecimento de moeda divisionária se processava com grande dificuldade.

\section{Catálogo}

\section{EMISSÃO I, SÉRIE 1}

Asse. VIVES LVXXXIV - 1.

Anv.: Cabeça de Hércules com pele de leão à esq.; atrás, clava; cercadura de pontos.

Rev.: Legenda indígena entre dois atuns à dir.; cercadura de pontos.

(132) Vives, A., op. cit. (v. nota 16), Est. LXXXIV.

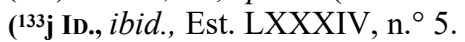

${ }^{\left({ }^{134}\right)}$ ID. ibid., Est. CXX, n. ${ }^{\circ} 3$. 
1. MNAE $153 / 75(13 \mathrm{~s}) \quad 15,51 \mathrm{~g} . \quad 27 \mathrm{~mm} . \quad 1 \mathrm{~h}$.

2. Gol. particular $\quad 14,92 \mathrm{~g} . \quad 27 \mathrm{~mm} . \quad 11 \mathrm{~h}$.

\section{SÉRIE 2}

Semisse. VIVES CXX -3 .

Anv. : Duas espigas ladeadas por um ou por dois glóbulos dentro de crescentes; cercadura de pontos.

Rev. : Hipocampo à esq. sobre legenda indígena; cercadura de pontos $\left({ }^{136}\right)$.

3. Pubi, por Rodríguez de

Berlanga ( $\left.{ }^{137}\right)$

---- $20 \mathrm{~mm}$.

4. MNAE $153 / 8(138)$

9,94 g. $\quad 24 \mathrm{~mm}$.

$8 h$.

\section{EMISSÃO II, SÉRIE 1}

Asse. VIVES LXXXIV -2

Any.: Como I, 1, mas, à frente, legenda latina: ODACIS-ARev.: Como I, 1.

5. MNAE $152 / 63(139140) \quad 11,68 \mathrm{~g} . \quad 26 \mathrm{~mm}$.

$12 \mathrm{~h}$.

6. MNAE $153 / 77(140) \quad 12,64 \mathrm{~g} .26 \mathrm{~mm}$.

$11 \mathrm{~h}$.

\section{SÉRIE 2}

Semisse. VIVES -

Anv.: Cabeça laureada de Neptuno à esq.; atrás, tridente; cercadura de pontos.

(135) Adquirida em Madrid: v. Vasconcellos, J. L. de, op. cit. (v. nota 20), p. 306; a numeração das moedas do M.N.A.E. diz respeito à sua colocação nos tabuleiros.

(136) O segundo exemplar é contramarcado com um $\mathrm{S}$ sobre a legenda indígena previamente apagada; sobre as razões deste processo v. supra, p. 95; parecem-nos inaceitáveis as premissas de que partiram Antunes, M. T. e Ca R Doso, J. L., Moedas de Cetovion. Novas observações, «Numisma», Lisboa, 41, 1986, p. 1-5.

(137) V. nota 7.

(138) Publicado por Vasconcellos, J. L. de, Antigualhas de Evoramonte, «O Archeologo Português», Lisboa, XXIII, 1918, p. 80.

(139) Proveniente de Mirobriga (Santiago do Cacém). Inédito.

(140) y. nota 135. 
EST. 1
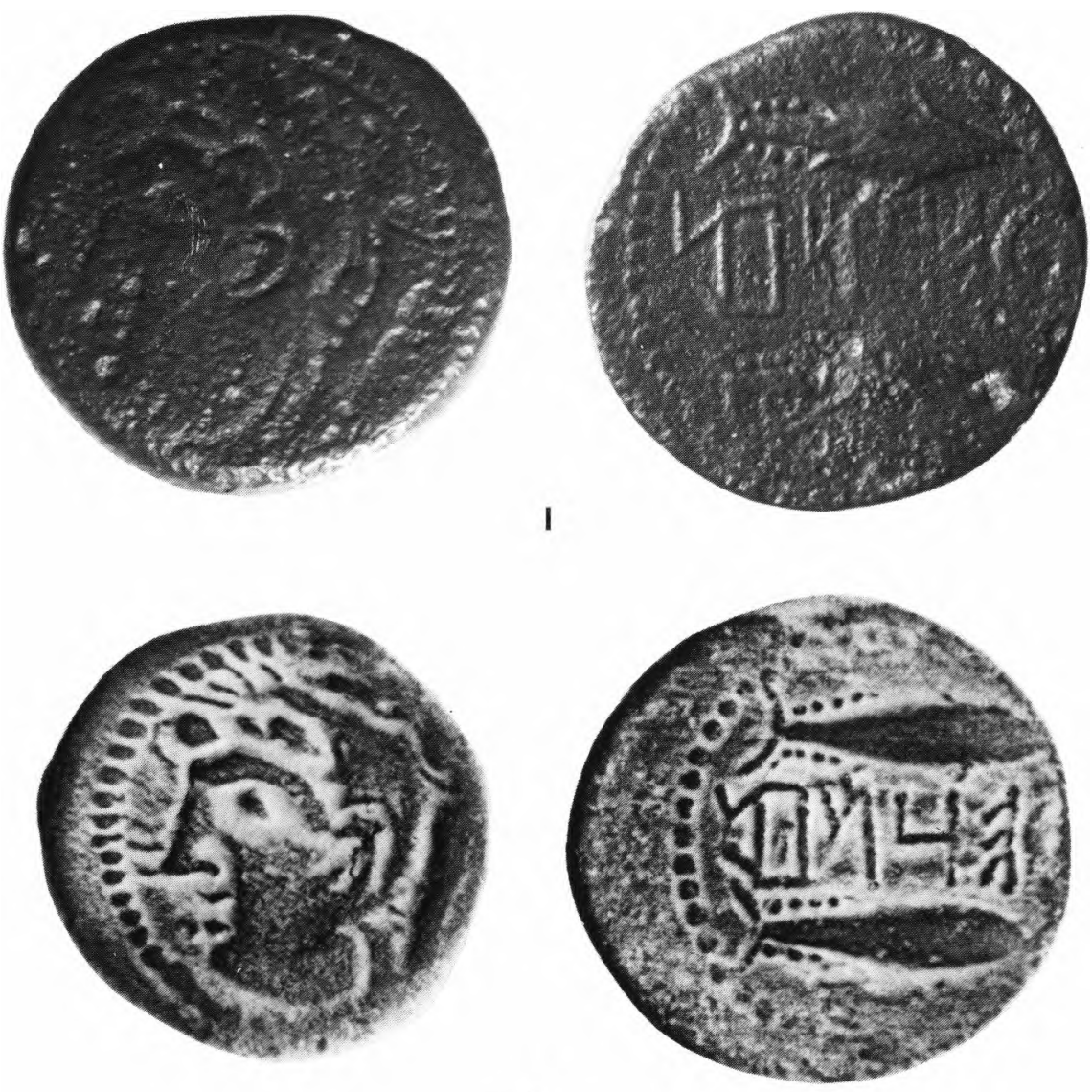

2
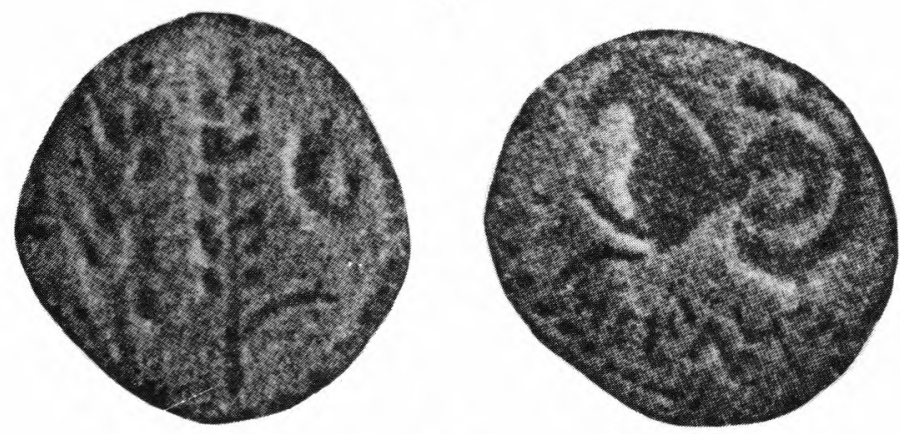

3 
EST. II

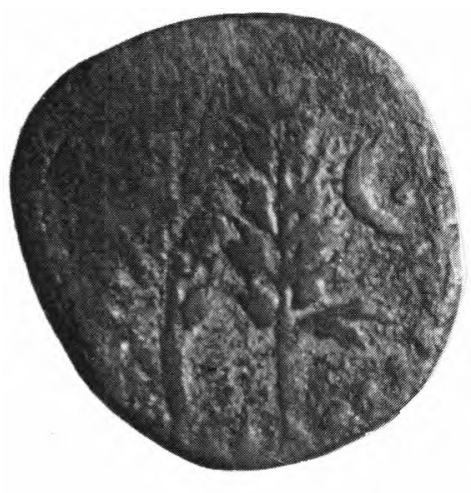

4
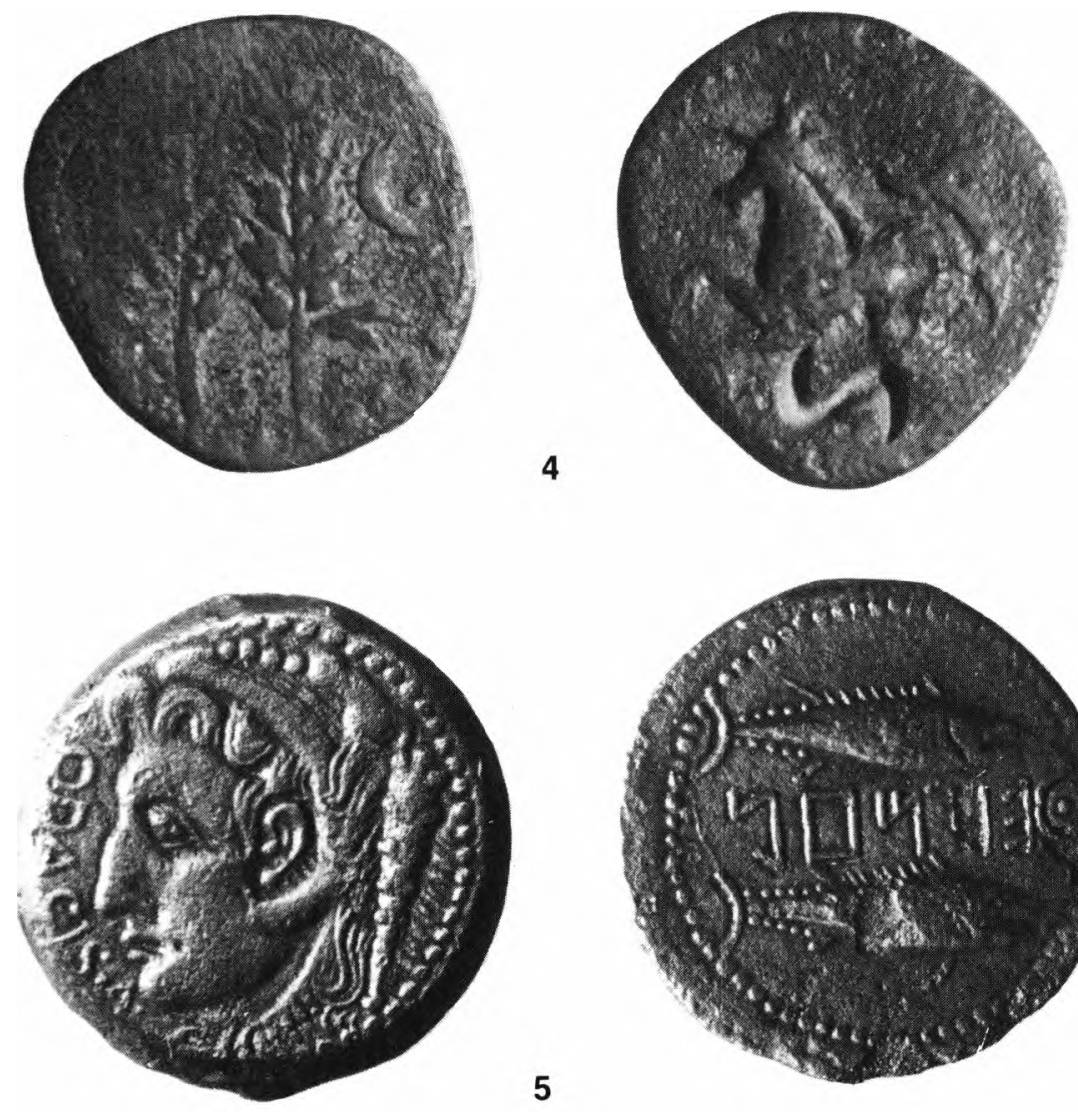

5
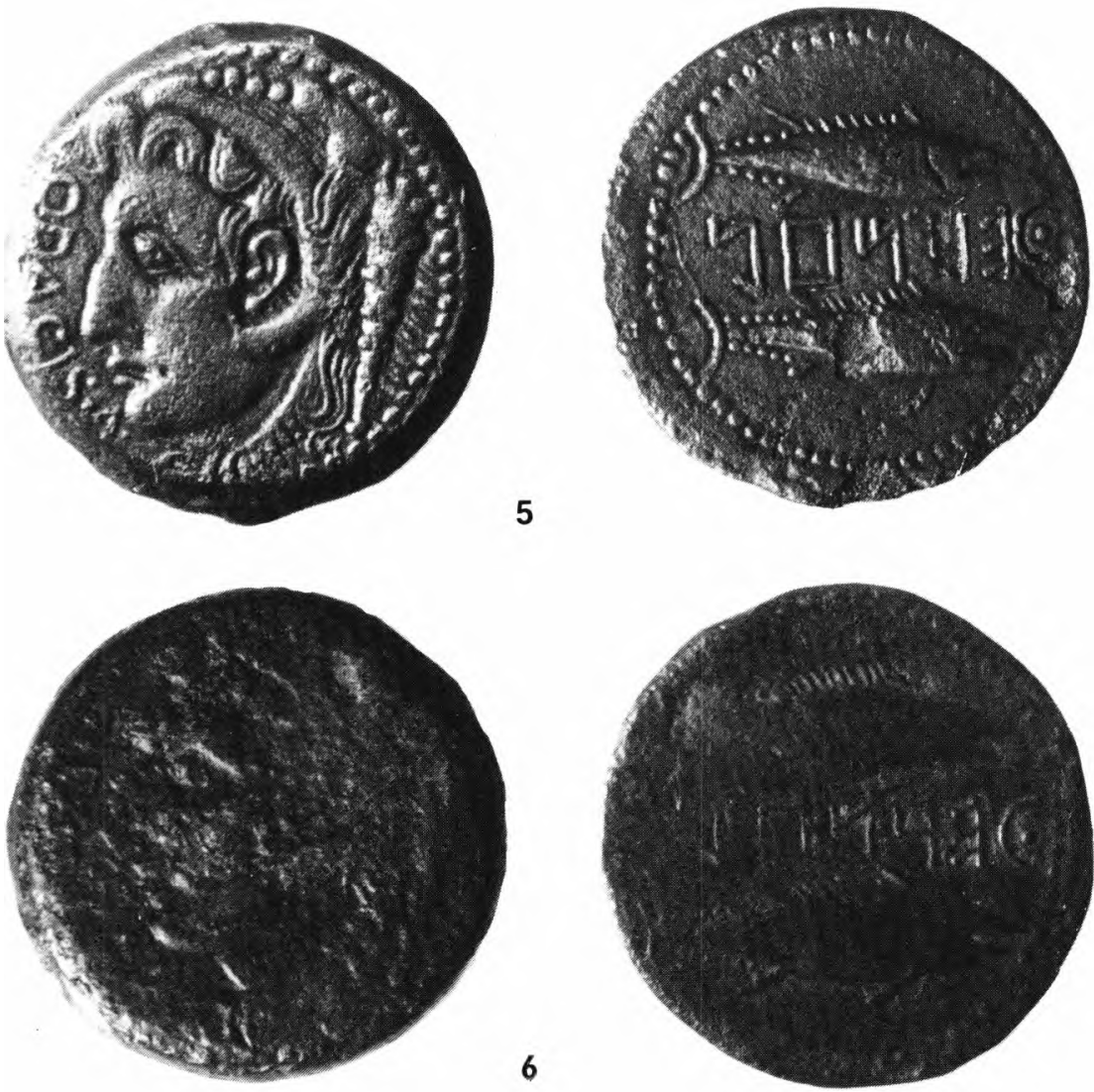

6

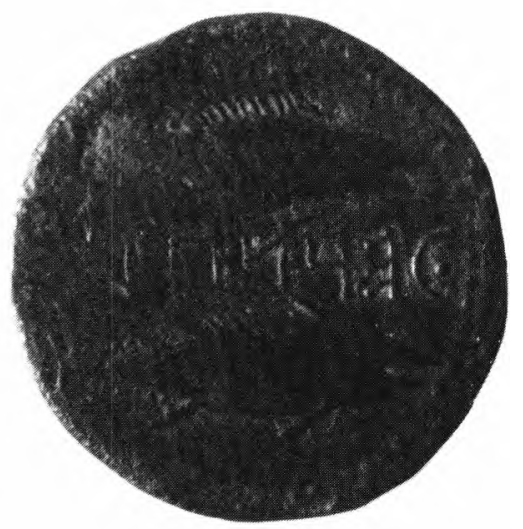


EST. Ill
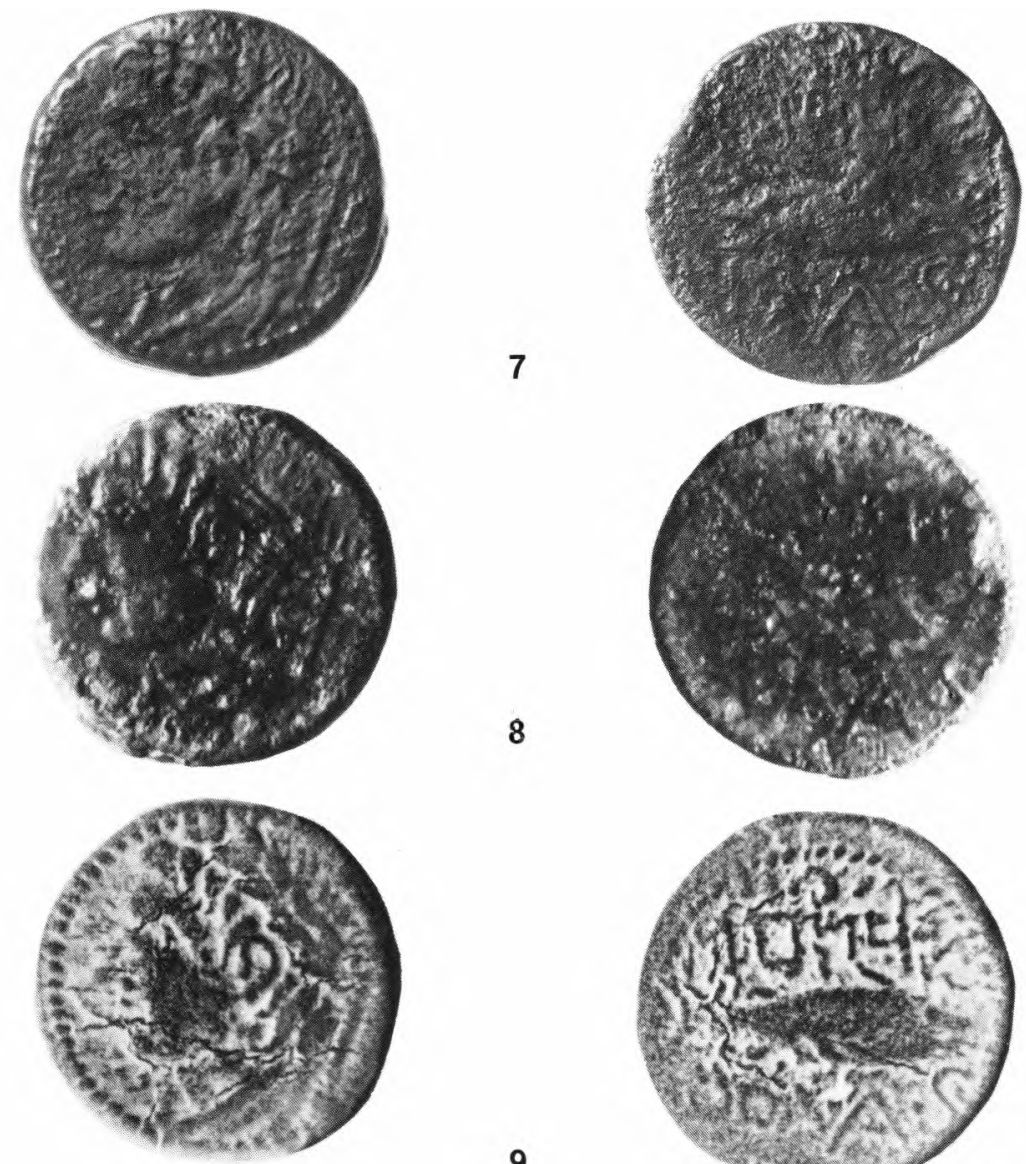

9
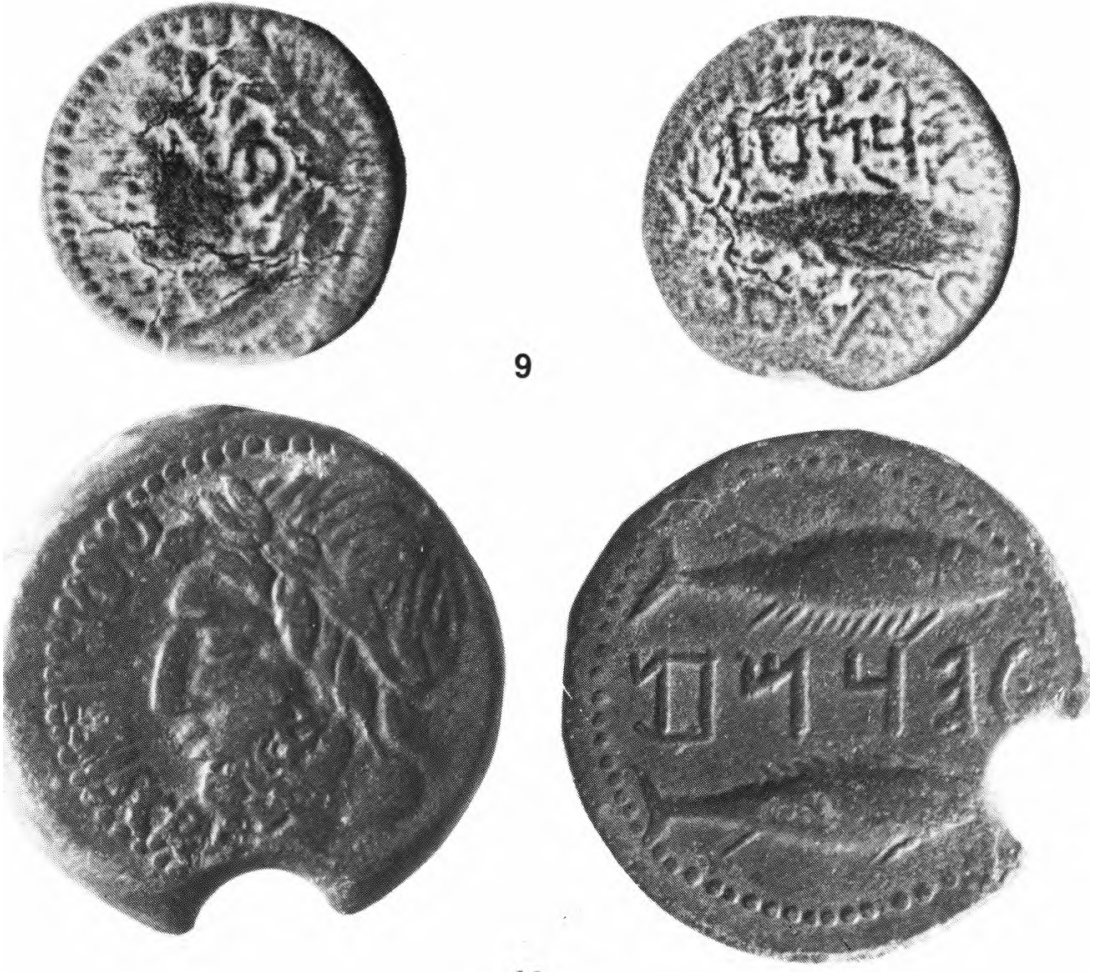

10 
EsT. IV
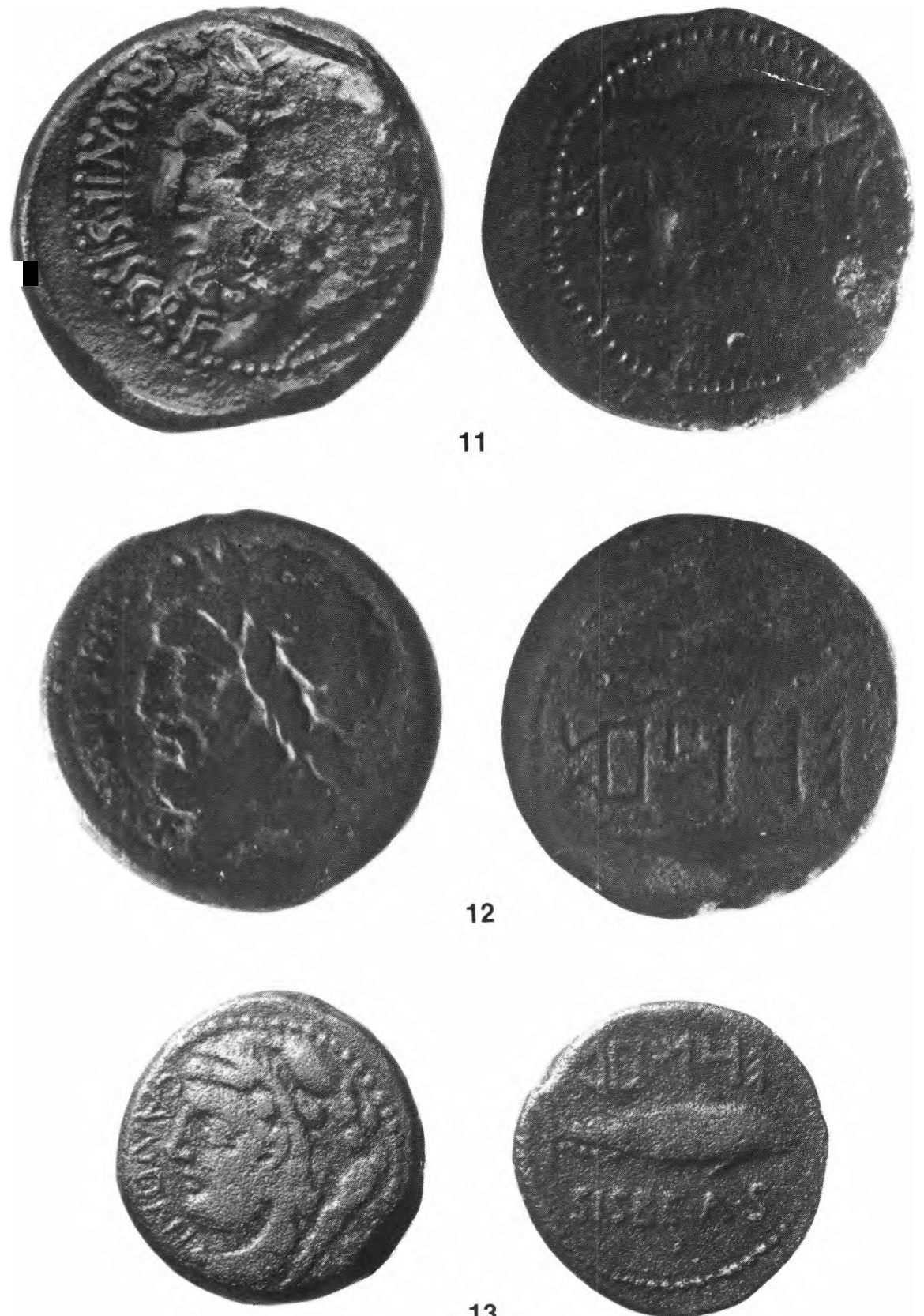

13

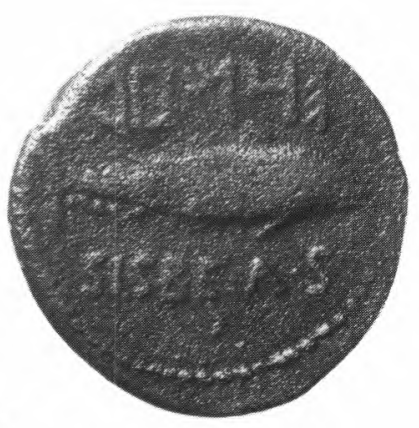


EsT. V
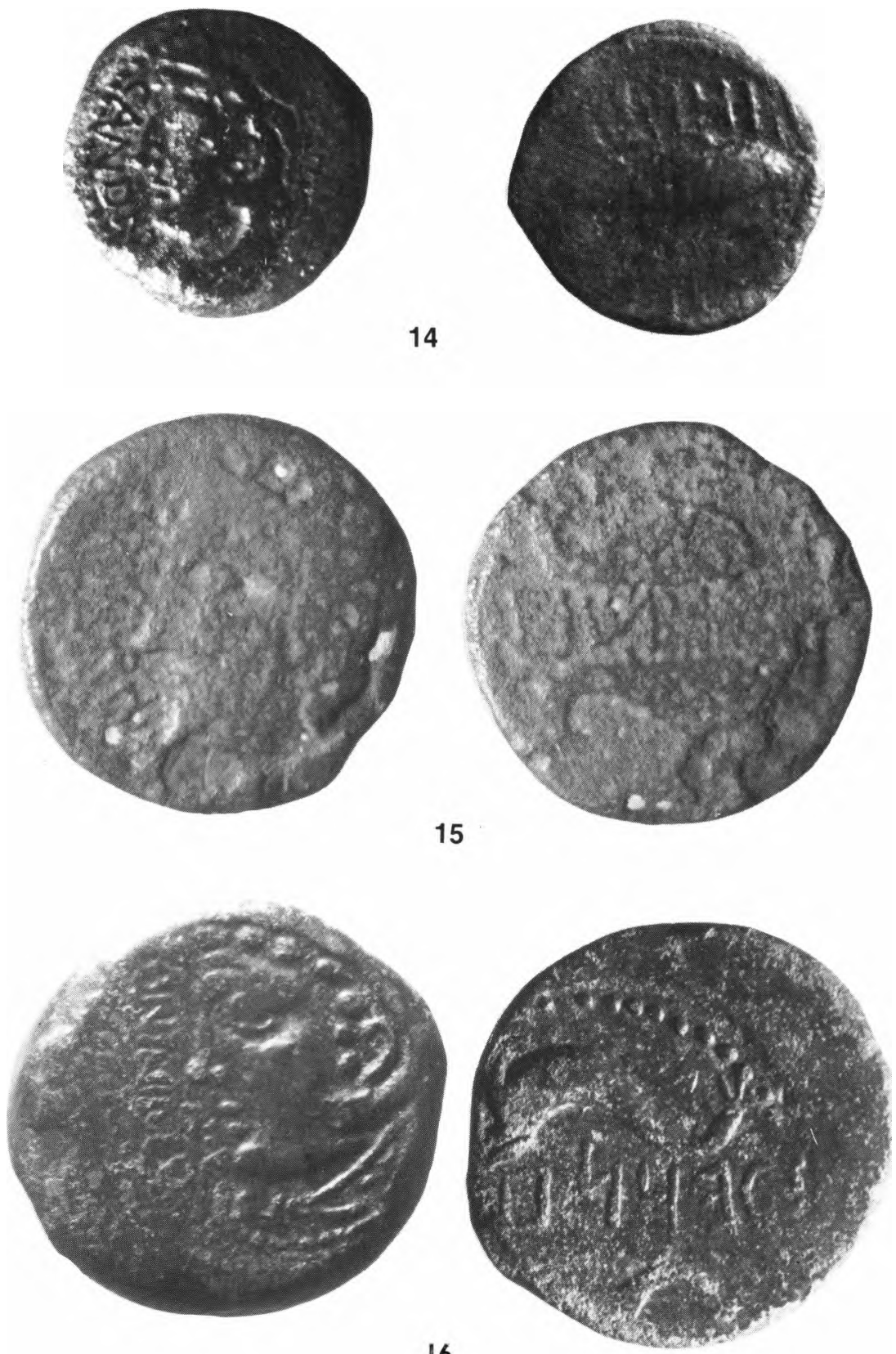

16 
EST. VI

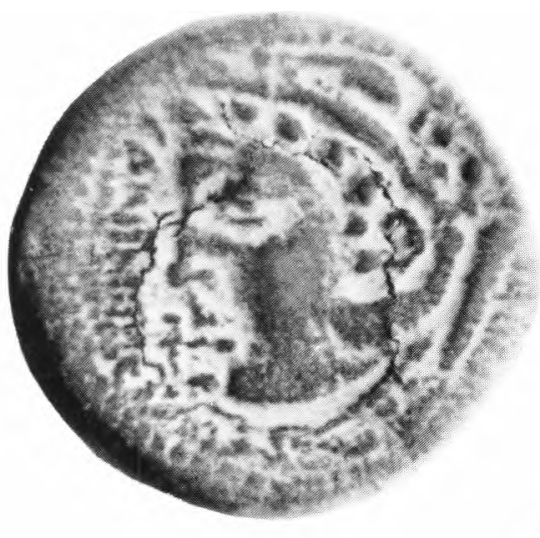

17
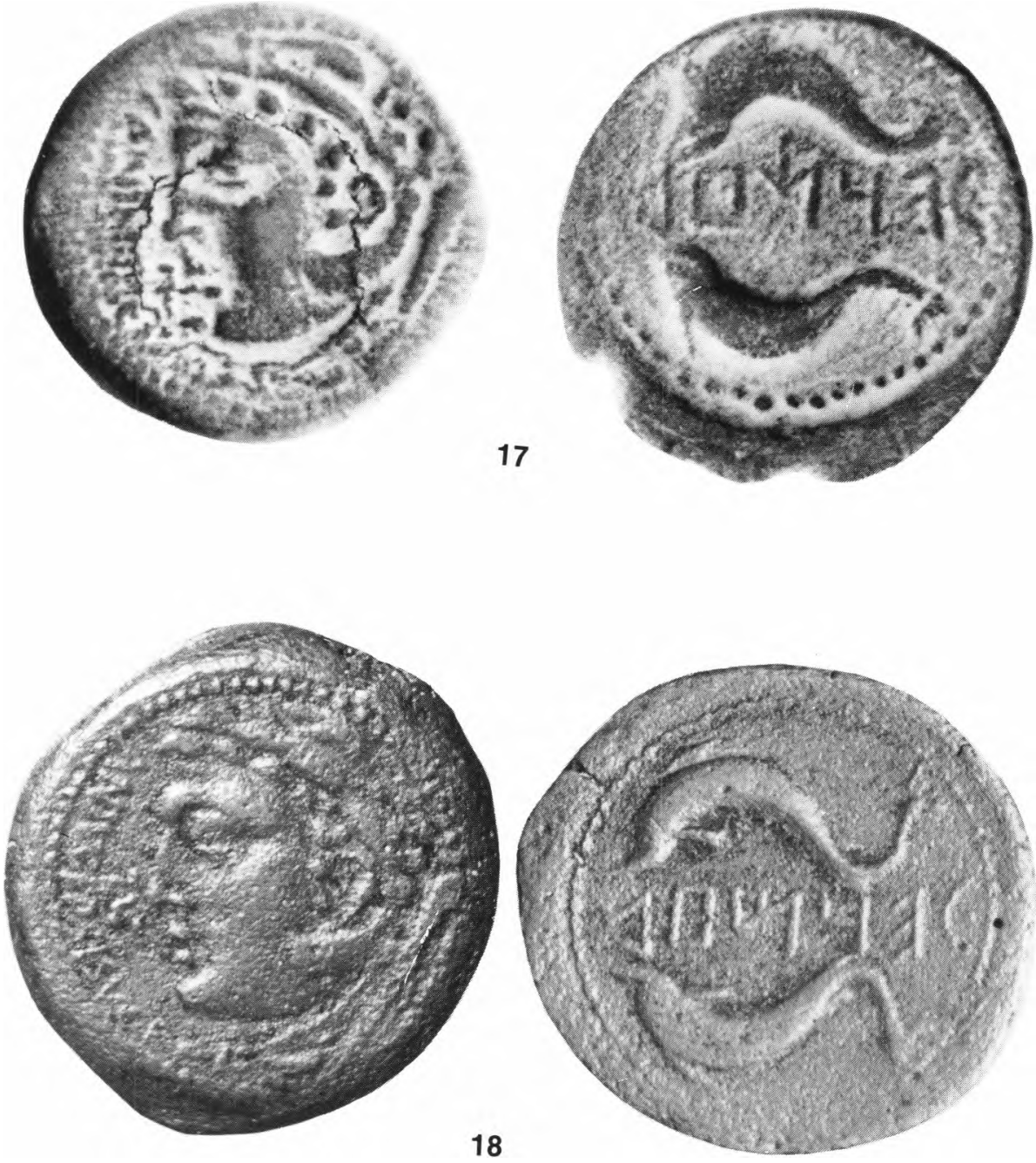
EST .VII

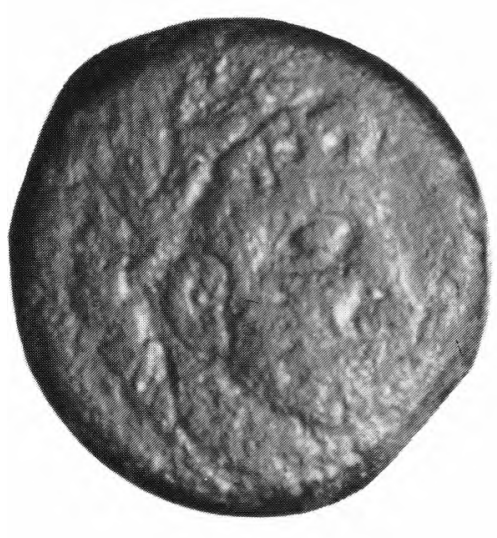

19
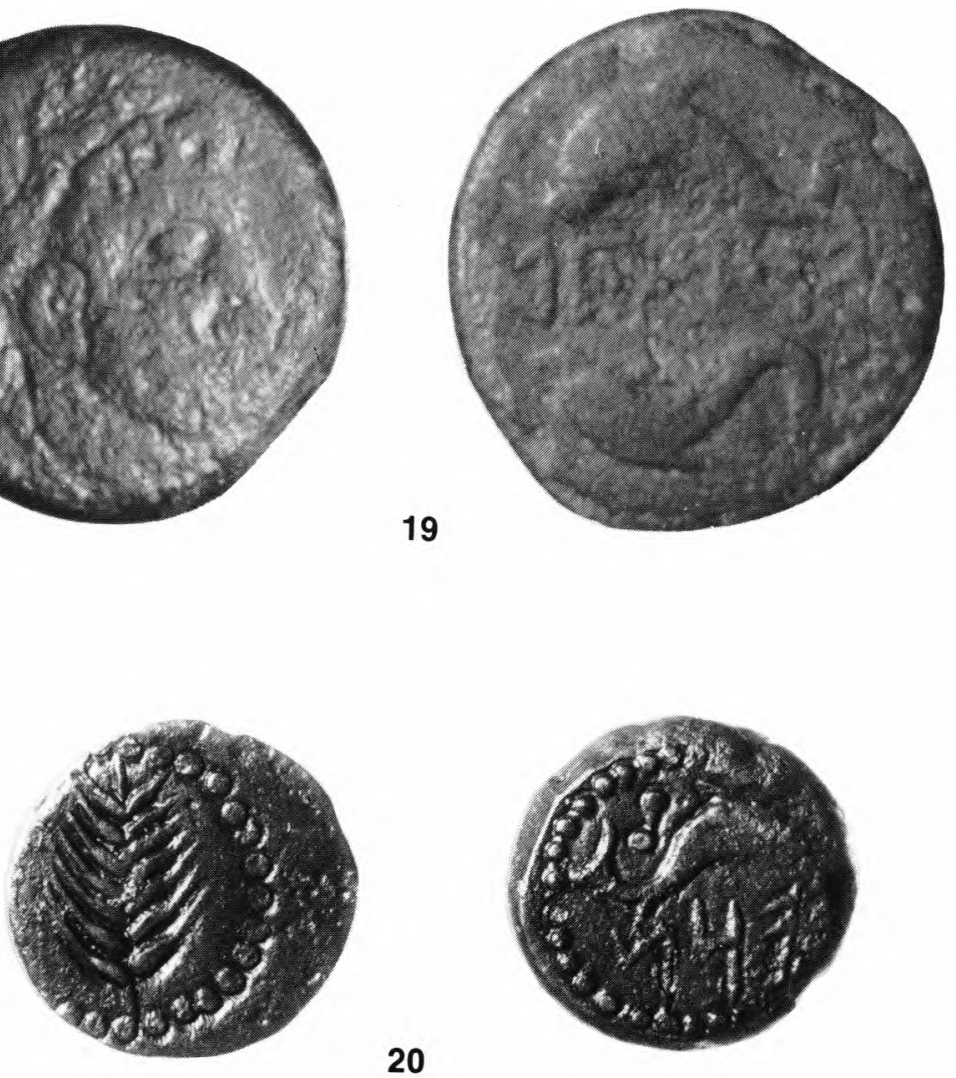
(Página deixada propositadamente em branco) 
Rev.: Atum à dir.; em cima, legenda indígena; em baixo, legenda latina: ODA-A-S* ; cercadura de pontos.

7. M.M.A.S. (141)

6,52 g. $19 \mathrm{~mm}$.

8. Miranda

$6,65 \mathrm{~g}$.

$18 \mathrm{~mm}$.

$11 \mathrm{~h}$.

9. Pubi, por Villaronga $\left({ }^{142}\right)$

$6,70 \mathrm{~g}$.

$19 \mathrm{~mm}$.

$12 \mathrm{~h}$.

EMISSÃO III, SÉRIE la

Asse. VIVES LXXXIV - 4.

Anv. : Cabeça laureada de Júpiter à esq.; à frente, legenda latina:

CAÑDNIL-SISCR-F; cercadura de pontos.

Rev. : Como I, 1.

$\begin{array}{lllll}\text { 10. M.N.A.E. } 335 / 19 & (143) & 14,82 \text { g. } & 27 \mathrm{~mm} . & 2 \mathrm{~h} . \\ \text { 11. M.N.A.E. } 336 / 6 & & 12,58 \text { g. } & 29 \mathrm{~mm} . & 6 \mathrm{~h} .\end{array}$

SÉRIE lb

Asse. Vives -

Anv. : Como o anterior, mas, à frente, legenda latina:

SISBE-SISCRA-F

Rev. : Como I, 1.

12. M.N.A.E. $154 / 16$

12,14 g. $\quad 26,5 \mathrm{~mm}$.

$4 \mathrm{~h}$.

SÉRIE 2

Semisse. VIVES LXXXIV - 3 .

Anv.: Como I, 1, mas, à frente, legenda latina: CANDNIL

Rev.: Como II, 1, mas, em baixo, legenda latina: SISBE-A-S-

13. Flamino $\left({ }^{144}\right) \quad 6,95$ g. $20 \mathrm{~mm} . \quad 6 \mathrm{~h}$.

(141) Museu Municipal de Alcácer do Sal; encontrado nesta vila, assim como as moedas n. ${ }^{\text {s }} 13,14,18$ e 20.

(142) Op. cit. (v. nota 10), p. 166, n. ${ }^{\circ} 474$.

(143) Publicado por Costa, A. I. M. da, Estações prehistóricas dos arredores de Setúbal, «O Archeologo Português», Lisboa, XY, 1910, p. 75-76, Est. IX, figs. 539-540; provém de Chibanes (Palmeia) e encontra-se actualmente no M.N.A.E. com o n. ${ }^{\circ}$ inv. 20582.

(144) Por falta de espaço, o L do letreiro do anverso não foi gravado neste cunho.

Conimbriga, 28 (1989), 71-99 
14. Daehnhardt $\left({ }^{145}\right) \quad 6,06$ g. $20 \mathrm{~mm} . \quad 1 \mathrm{~h}$.

\section{EMISSÃO IV}

Asse. VIVES LXXXIV - 6 .

Anv. : Cabeça de Neptuno à esq.; atrás, tridente; à frente, legenda latina : SISVCVRHIL; cercadura de pontos.

Rev.: Legenda indígena entre dois golfinhos à dir.; cercadura de pontos.

15. M.N.A.E. $\left.153 / 76 \mathrm{C}^{46}\right) \quad 10,30$ g. $26 \mathrm{~mm} . \quad 7 \mathrm{~h}$.

\section{EMISSÃO V}

Asse. VIVES -.

Anv.: Como I, 1, mas, à frente, legenda latina: CANTNIP[EDNI ?]/ÃE-F

Rev. : Legenda indígena entre dois golfinhos à esq. ; cercadura de pontos.

16. M.N.A.E. $186 / 42 \mathrm{C}^{47}$ ) $\quad 14,98$ g. $28 \mathrm{~mm} . \quad 2 \mathrm{~h}$.

17. Col. particular $29 \mathrm{~mm}$. $1 \mathrm{~h}$.

\section{EMISSÃO VI}

Asse. VIVES-.

Anv.: Como I, 1, mas, à frente, legenda latina: ANDVGEP-SISVCF-/TVL

Rev.: Como V.

18. Gambetta $\quad 13,34$ g. $30 \mathrm{~mm}$. $1 \mathrm{~h}$.

(145) Publicado por Vasconcellos, J. L., op. cit., (v. nota 20), p. 305. (i«j V. nota 135.

(147) Publicado por Santos, M. F. dos, cit. (v. nota 15) p. 495. 


\section{EMISSÃO VII}

Semisse. VIVES LXXXIV -8 .

Anv.: Gomo I, 1, mas, à frente, legenda latina: COR[ANI?]

Rev. :Skyphos(?) sobre legenda indígena.

\section{EMISSÃO VIII, SÉRIE 1}

Asse. VIVES LXXXIV - 5 .

Anv.: Cabeça laureada de Hércules à dir.; atrás, clava; cercadura de pontos.

Rev. : Como V.

19. Diogo 15,14 g. $26 \mathrm{~mm}$.

$7 \mathrm{~h}$.

\section{SÉRIE 2}

\section{Semisse. VIVES-.}

Anv.: Espiga vertical; cercadura de pontos.

Rev.: Golfinho à dir. sobre legenda indígena; em cima, dois pontos unidos por uma recta; cercadura de pontos.

20. Gomes

7,70 g. $\quad 17,5 \mathrm{~mm}$.

$7 \mathrm{~h}$.

\section{Agradecimentos}

Desejamos agradecer vivamente a amabilidade de todos os colecionadores que se prontificaram a ceder algumas das suas peças para estudo: Sr. Rainer Daehnhardt (Belas), Dr. A. M. Dias Diogo (Lisboa), Sr. Augusto Flamino (Alcácer do Sal), Eng. ${ }^{\circ}$ Agostinho Ferreira Gambetta (Lisboa), Sr. Fernando Gomes (Alcácer do Sal), Sr. José Rodrigues Marinho (Lisboa) e Eng. ${ }^{\circ}$ J. A. Godinho Miranda (Lisboa). Os nossos agradecimentos são extensíveis aos responsáveis pelas colecções públicas que contribuíram para a realização deste trabalho, designadamente os Drs. Francisco Alves e Ana Isabel Santos, do Museu Nacional de Arqueologia e Etnologia, e o Dr. João Carlos Lázaro Faria, do Museu Municipal de Alcácer do Sal. 